\title{
An Update on the Effects of Probiotics on Gastrointestinal Cancers
}

\author{
Amirhossein Davoodvandi ${ }^{1,2}$, Farzaneh Fallahi ${ }^{3}$, Omid Reza Tamtaji ${ }^{4}$, Vida Tajiknia ${ }^{5}$, \\ Zarrin Banikazemi ${ }^{3}$, Hadis Fathizadeh ${ }^{6}$, Mohammad Abbasi-Kolli $^{7}$, Michael Aschner ${ }^{8}$, \\ Maryam Ghandali ${ }^{9 *}$, Amirhossein Sahebkar ${ }^{10,11 *}$, Mohsen Taghizadeh ${ }^{3}$ and \\ Hamed Mirzaei ${ }^{3 *}$
}

${ }^{1}$ Student Research Committee, Kashan University of Medical Sciences, Kashan, Iran, ${ }^{2}$ Network of Immunity in Infection, Malignancy and Autoimmunity (NIIMA), Universal Scientific Education and Research Network (USERN), Tehran, Iran, ${ }^{3}$ Research Center for Biochemistry and Nutrition in Metabolic Diseases, Institute for Basic Sciences, Kashan University of Medical Sciences, Kashan, Iran, ${ }^{4}$ Students' Scientific Research Center, Tehran University of Medical Sciences, Tehran, Iran, ${ }^{5}$ Department of

OPEN ACCESS

Edited by:

Stefano Fiorucci,

University of Perugia, Italy

Reviewed by:

Dan-Lucian Dumitrașcu, Iuliu Hatieganu University of Medicine and Pharmacy, Romania Veronica Ojetti, The Catholic University of America,

Rome Campus, Italy Jose A. Uranga

Rey Juan Carlos University, Spain

*Correspondence:

Maryam Ghandall ghandali.maryam@gmail.com

Amirhossein Sahebkar amir_saheb2000@yahoo.com Hamed Mirzaei

mirzaei-h@kaums.ac.ir h.mirzaei2002@gmail.com

Specialty section: This article was submitted to Gastrointestinal and Hepatic Pharmacology,

a section of the journal

Frontiers in Pharmacology

Received: 15 March 2021 Accepted: 26 November 2021 Published: 21 December 2021

Citation:

Davoodvandi A, Fallahi F, Tamtaji OR, Tajiknia V, Banikazemi Z, Fathizadeh H, Abbasi-Kolli M, Aschner M, Ghandali M, Sahebkar A, Taghizadeh M and Mirzaei H (2021) An Update on the Effects of Probiotics on

Gastrointestinal Cancers. Front. Pharmacol. 12:680400. doi: $10.3389 /$ fphar.2021.680400 Surgery, School of Medicine, Iran University of Medical Sciences, Tehran, Iran, ${ }^{6}$ Department of Laboratory Sciences, Sirjan Faculty of Medicine Sciences, Sirjan, Iran, ${ }^{7}$ Department of Medical Genetics, Faculty of Medical Sciences, Tarbiat Modares University, Tehran, Iran, ${ }^{8}$ Department of Molecular Pharmacology, Albert Einstein College of Medicine, Bronx, NY, United States, ${ }^{9}$ School of Medicine, Iran University of Medical Sciences, Tehran, Iran, ${ }^{10}$ Applied Biomedical Research Center, Mashhad University of Medical Sciences, Mashhad, Iran, ${ }^{11}$ Biotechnology Research Center, Pharmaceutical Technology Institute, Mashhad University of Medical Sciences, Mashhad, Iran

Because of their increasing prevalence, gastrointestinal (Gl) cancers are regarded as an important global health challenge. Microorganisms residing in the human Gl tract, termed gut microbiota, encompass a large number of living organisms. The role of the gut in the regulation of the gut-mediated immune responses, metabolism, absorption of micro- and macronutrients and essential vitamins, and short-chain fatty acid production, and resistance to pathogens has been extensively investigated. In the past few decades, it has been shown that microbiota imbalance is associated with the susceptibility to various chronic disorders, such as obesity, irritable bowel syndrome, inflammatory bowel disease, asthma, rheumatoid arthritis, psychiatric disorders, and various types of cancer. Emerging evidence has shown that oral administration of various strains of probiotics can protect against cancer development. Furthermore, clinical investigations suggest that probiotic administration in cancer patients decreases the incidence of postoperative inflammation. The present review addresses the efficacy and underlying mechanisms of action of probiotics against $\mathrm{Gl}$ cancers. The safety of the most commercial probiotic strains has been confirmed, and therefore these strains can be used as adjuvant or neo-adjuvant treatments for cancer prevention and improving the efficacy of therapeutic strategies. Nevertheless, well-designed clinical studies are still needed for a better understanding of the properties and mechanisms of action of probiotic strains in mitigating Gl cancer development.

Keywords: probiotic, gastrointestinal disorders, cancer, pathology, therapy

\section{INTRODUCTION}

The incidence of gastrointestinal (GI) neoplasms is rapidly increasing globally (Ashrafizadeh et al., 2020; Pourhanifeh et al., 2020; Shafabakhsh et al., 2021). GI cancers are a complex set of heterogenous diseases and disorders (Wang et al., 2021) and are classified into more frequent sporadic and rare inherited forms. Environmental and genetic risk factors can cooperatively alter normal tissue into a precursor or a premalignant injury, culminating in malignancy. While the 
precise genetic mechanisms are somewhat understood in a tissuetype- and cell-type-specific context, many common aspects exist between GI cancers of heterogenous origin (Wang et al., 2021). Consistent with the advances made in developing new diagnostic and therapeutic approaches for GI cancers, several probiotic strains are being used as nutritional supplements.

Probiotics are a group of viable microorganisms including bacteria and yeasts that if consumed in sufficient amounts, may afford health benefits to the host (Ganguly et al., 2011; Tamtaji et al., 2019a; Tamtaji et al., 2019b; Alipour Nosrani et al., 2021; Davoodvandi et al., 2021). The major advantage of probiotic administration is its ability to maintain gut microbial homeostasis, reduce pathogenic microorganisms in the GI tract, and restores homeostasis of intestinal microorganisms (Floch et al., 2011; Butt and Epplein, 2019). Moreover, by modulating microbiota and immune responses, decreasing bacterial translocation, promoting the function of the gut barrier, inducing antiinflammatory properties, triggering anti-pathogenic activity, and decreasing tumor development and metastasis, probiotics might contribute to the prevention and treatment of GI cancers (Servin, 2004; Cotter et al., 2005; Javanmard et al., 2018). Considering the potential roles of Helicobacter pylori (H. pylori) in the initiation of colorectal (Teimoorian et al., 2018; Butt and Epplein, 2019) and gastric cancers (Alfarouk et al., 2019), the possible properties of probiotics against GI neoplasm in humans have been investigated in relation to their suppressive effects on $\mathrm{H}$. pylori (Taremi et al., 2005; Sanders et al., 2013; Russo et al., 2014; Khoder et al., 2016; Rasouli et al., 2017). By triggering immune activity, probiotics, as functional dietary supplements, may mitigate neoplastic predisposition and development of GI cancers (Liong, 2008; Zuccotti et al., 2008; Kumar et al., 2010; De Preter et al., 2011; Zhang et al., 2011).

\section{CLINICAL OVERVIEW ON GI NEOPLASMS}

Carcinogenesis is a multistage process characterized by genetic mutations (Nowell, 1976; Yuasa, 2003; Vogelstein and Kinzler, 2004). In the past, initiation and progression of tumors were considered as distinct processes. A critical observation that led to the multistage hypothesis was that neoplasm was clonal, with each neoplastic cell originating from a single progenitor (Nowell, 1976; Cahill et al., 1999). This model implied that genetic mutations required for neoplastic transformation did not occur at once, but rather progressively. With each stage in this process, the transforming cell obtained a new mutation that promoted cell survival or proliferation.

A cell clone was developed with all of the necessary aspects for neoplastic transformation through evolution or natural selection. Selection is a critical element of this process because mutations are random events; thus, only rare mutations result in activation of cell survival and growth-promoting pathways or inactivation of apoptotic pathways or tumor suppressors (Ponder, 2001). These mutations impart a selective survival and growth dominance to that cell and its progeny. This leads to the expansion of that cell into a clonal population. Further mutations that occur in cells of that clonal population provide a few rare cells with new superiority. These daughter cells are subjected to an additional round of clonal expansion. This process continues, building on round after round of clonal expansion, till a mass is generated, and neoplastic transformation has taken place (Nowell, 1976; Cahill et al., 1999).

The specific number of somatically acquired gene mutations necessary for neoplastic transformation is dependent upon which genes and tissues are targeted. In common solid tumors, such as those derived from the colon or pancreas, an average of 33-66 genes displays subtle somatic mutations that would be expected to alter their protein products. About $95 \%$ of these mutations are single-base substitutions (such as $\mathrm{C}>\mathrm{G}$ ), whereas the remainder are deletions or insertions of one or a few bases (such as CTT > CT). Of the base substitutions, $90.7 \%$ result in missense changes, $7.6 \%$ result in nonsense changes, and $1.7 \%$ result in alterations of splice sites or untranslated regions immediately adjacent to the start and stop codons (Vogelstein et al., 2013).

Typically, benign dysplastic intermediates develop before GI neoplasm. Indeed, they do not originate from normal tissues directly, and the dysplastic lesions are characterized by their morphology and categorized based on certain pathological indicators (Said, 2012). For example, in the colon, the adenoma-carcinoma pattern shows this promotion from normal mucosa to invasive carcinoma via dysplastic intermediates. This pattern has been well supported by many pathological and animal studies (Kim and Lance, 1997; Lynch and Hoops, 2002).

The same multistep pattern from normal tissue via dysplastic intermediates to malignancy has been shown for human pancreatic, esophageal, and gastric cancers (Hruban et al., 2001; Yuasa, 2003; Hruban et al., 2004; Lin and Beerm, 2004). Cancer always emerges in a dysplastic precursor lesion that is histologically or grossly apparent. Current models have shown that the sequence of events prior to intestinal gastric cancer is as follows: atrophic gastritis, intestinal-metaplasia, and adenomas, which develop into carcinomas (Yuasa, 2003). Precursor lesions that lead to pancreatic cancer have been formally agreed upon, and the characteristics necessary for their classification have been established (Hruban et al., 2001; Hruban et al., 2004). These criteria classify the pancreatic lesions for both scientific and clinical uses.

The concept of cancer stem cells highlighted new perspectives in understanding this disease. Although it is tempting to explain tumor formation and metastasis by the presence of stem cells, after almost a decade of intense research, it seems that cancer stem cells fail to explain how neoplasia evolves. It seems most likely that this population of cells is not a defined group of cells resting in a niche and populating the tumor with amplifying cells, but rather, that few or maybe multiple cells within the tumor can function as cancer stem cells if induced, yet also revert to the state of a "normal" cancer cell. In general, cancer stem cells resulting from mutations in stem/progenitor cells most likely undergo uncontrolled proliferation (Li and Neaves, 2006; Abdul Khalek et al., 2010; Welte et al., 2010).

\section{PROBIOTIC AND CANCER THERAPY}

Advances have been made over the last century to develop anticancer drugs that lead to drastically reducing of the side effects of medications (Falzone et al., 2018). However, the 
beneficial effects of probiotics on metabolic profiles and biomarkers of inflammation and oxidative stress were previously reported (Asemi et al., 2012a; Asemi et al., 2012b; Tajadadi-Ebrahimi et al., 2014; Bahmani et al., 2016). Modifying the intestinal microbiome with oral probiotics has been applied to decrease side effects associated with drugs. The adverse effects caused by anticancer treatments mainly include mucositis and diarrhea. Among the advantages of probiotics are their low cost and general safety (Rondanelli et al., 2017). Probiotic application in clinical practice has displayed a wide range of advantages, such as improving antibiotics and Clostridium difficile-related diarrhea and respiratory tract infections (Rondanelli et al., 2017). Populating the gut microbiota in cancer patients with probiotics re-establishes both the functionality and quantities of commensal bacteria, which are reduced after treatments (Zitvogel et al., 2018). Nonetheless, probiotic administration in several clinical trials has been shown to re-establish healthy intestinal microbiota composition and to diminish diarrhea and other treatment-related damages to the gut, such as mucositis (Mego et al., 2013). Consistently, Lactobacillus containing probiotics prevent diarrhea and mucositis in individuals, who received chemotherapy/radiotherapy for pelvic malignancy (Gianotti et al., 2010; Lalla et al., 2014).

The specific mechanism associated with the antitumor properties of probiotics remains unclear. Gut microbiota affect a variety of pathways, which are considered to play a central role in this process. Primarily, probiotic bacteria play an essential role in the preservation of homeostasis, thus maintaining sustainable physicochemical conditions in the colon. Reduced $\mathrm{pH}$ causing inter alia by the excessive presence of bile acids in feces may be a direct cytotoxic factor affecting colonic epithelium leading to colon carcinogenesis. Regarding their involvement in the modulation of the $\mathrm{pH}$ and bile acid profile, probiotic bacteria, such as L. acidophilus and B. bifidum, have shown efficacy in cancer prevention (Biasco et al., 1991; Bernstein et al., 2005; Jia et al., 2018).

Probiotic strains are also responsible for maintaining the balance between the quantity of other participants of natural intestinal microflora and their metabolic activity. Putrefactive bacteria, such as Escherichia coli and Clostridium perfringens, naturally present in the gut, have been proven to be involved in production of carcinogenic compounds using enzymes such as $\beta$-glucuronidase, azoreductase, and nitroreductase (Górska et al., 2019).

Another cancer-preventing strategy involving probiotic bacteria, such as chiefly Lactobacillus and Bifidobacillus strains, has been linked to the binding and degradation of potential carcinogens. Mutagenic compounds associated with the increased risk of colon cancer are commonly found in unhealthy food, especially fried meat. Ingestion of the Lactobacillus strain by human volunteers alleviated the mutagenic effect of diet rich in cooked meat, which resulted in decreased urinary and fecal excretion of heterocyclic aromatic amines (HAAs) (Lidbeck et al., 1992; Hayatsu and Hayatsu, 1993; Górska et al., 2019).

Many beneficial compounds produced and metabolized by gut microbiota have been demonstrated to play an essential role in maintaining homeostasis and suppressing carcinogenesis. A specific population of gut microbiota is dedicated to the production of short-chain fatty acids (SCFAs) such as acetate, propionate, and butyrate as a result of the fermentation of fiberrich prebiotics. Except for their principal function as an energy source, SCFAs have also been proven to act as signaling molecules affecting the immune system, cell death, and proliferation as well as intestinal hormone production and lipogenesis, which explains their crucial role in epithelial integrity maintenance (Garrett, 2015; Requena et al., 2018; Górska et al., 2019).

Figure 1 shows both the advantages and potential disadvantages of probiotic administration as adjuvants during cancer treatments. The figure highlights show probiotics' regulation of the gut's subtle equilibrium, from microbial imbalance (dysbiotic) to functional and healthy microbiota.

\section{EFFECTS OF PROBIOTICS ON GASTROINTESTINAL CANCER CELLS}

\section{Probiotics and Gastric Cancer}

$H$. pylori-mediated inflammation is one of the potential factors in the induction of gastric cancer in infected populations (Moss, 2017). Evidence evaluating the anti-gastric cancer effects of probiotics has focused on $H$. pylori-induced pathophysiology of this type of cancer. Maleki-Kakelar and others reported that by mediating numerous molecular pathways, Lactobacillus plantarum (L. plantarum) caused significant inhibitory effects on the $H$. pylori growth rate. Upon downregulation of the AKT gene and upregulation of the phosphatase and tensin homolog (PTEN), Bcl-2-associated X (Bax), and toll-like receptor 4 (TLR4), L. plantarum significantly inhibited the proliferation of AGS and CRL-1739 human gastric cell lines (MalekiKakelar et al., 2020). Interleukin-8 (IL-8) is an inflammatory chemokine that plays critical roles in inflammatory pathways (Meniailo et al., 2018). In the human gastric epithelial cell line-1 (GES-1), Lactobacillus bulgaricus (L. bulgaricus) inhibited the production of IL-8. In addition, Lactobacillus acidophilus (L. acidophilus) and L. bulgaricus inhibited adhesion of $H$. Pylori to GES-1 cells that attenuated inflammation in these cells (Song et al., 2019). Lin et al. reported that supplementation with Lactobacillus fermentum P2 (L. bacillus P2), L. casei L21, L. rhamnosus JB3, or their combination in $H$. pylori-infected mice reduced the expression level of interferon gamma (IFN$\gamma$ ) along with interleukin-1 beta (IL-1 $\beta$ ). Besides, H. pylori concentrations in the stomach of infected mice were decreased after probiotic supplementation (Lin et al., 2020). Another study demonstrated that $L$. acidophilus, $L$. plantarum, and $L$. rhamnosus supplementation significantly attenuated $H$. pyloriinduced inflammation in vivo (Asgari et al., 2020). As mentioned earlier, most of the anti-gastric cancer studies have been directed at the inhibitory effects on $H$. pylori infection. Further experimental studies are needed for evaluating the effects of probiotic on gastric cancer inhibition mechanistically.

Ornithine decarboxylase is a crucial enzyme in the polyamine biosynthesis pathway and is responsible for catalyzing the decarboxylation of ornithine into putrescine (Svensson et al., 


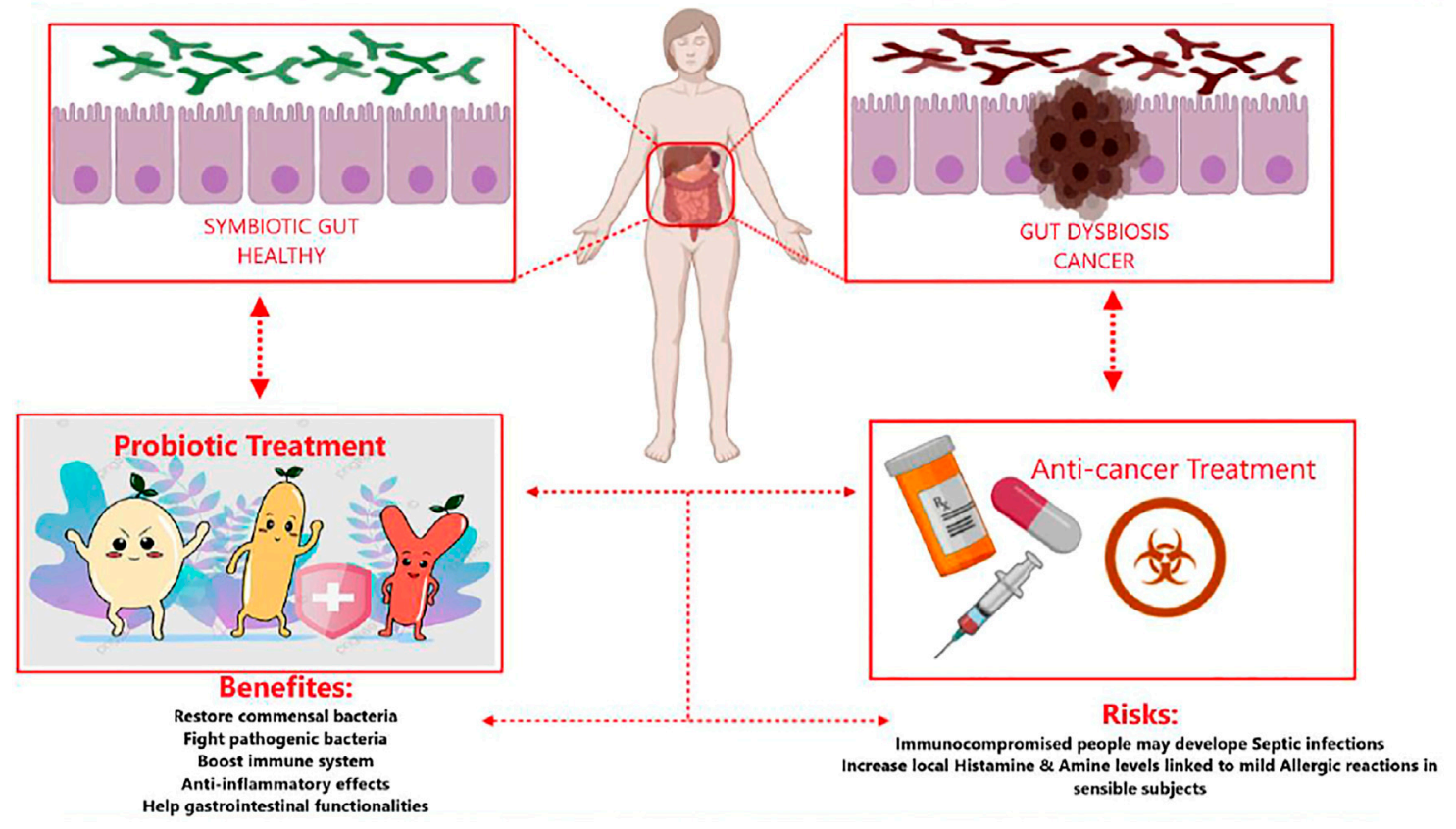

FIGURE 1 | Risks and benefits of probiotics associated with cancer treatment. Schematic depiction of healthy gut microbiota in humans, occupied by symbiotic bacteria (top left box) against tumor-affected microbiota and dysbiosis of the gut (top right box). Anticancer treatment may negatively influence gut microbiota, leading to dysbiotic unbalance (bottom right square). Probiotic administration may re-adjust the dysbiotic conditions mediated by tumor growth and treatment. Probiotics may improve gastrointestinal therapy-related side effects, so they re-establish the intestinal symbiosis (bottom left square). The application of probiotics in anticancer therapy has benefits and risks (central bottom box).

2008). Ornithine decarboxylase is a neovascularization agent in tumoral cells and has been overexpressed in tumors of epithelial origin including colorectal, prostate, and gastric cancers (Ma et al., 2007). Russo and others demonstrated that treatment with L. rhamnosus GG homogenate and cytoplasm extracts significantly decreased the activity of ornithine decarboxylase, reducing the polyamine content of HGC-27 human gastric cancer cells. Furthermore, in comparison with the untreated control group, probiotic treatment considerably increased the ratio of Bax/Bcl-2 (Russo et al., 2007). Xie and others reported that 8-day postoperative probiotic supplementation in gastric cancer patients significantly reduced diarrhea occurrence. Furthermore, in probiotic-induced patients, the expression level of interleukin-6 (IL-6), interleukin-8 (IL-8), and tumor necrosis factor alpha (TNF- $\alpha$ ) was significantly decreased compared with that in patients in the control group (Xie et al., 2018).

The urokinase plasminogen activator (uPA) is an important serine proteinase enzyme which catalyzes the production of active protease plasmin from its proenzyme plasminogen (Pavón et al., 2016; Mahmood et al., 2018). The activation of the uPA is dependent on the expression of the $\mathrm{uPA}$ receptor ( $\mathrm{UPAR}$ ) in the cell surface. By increasing the activity of matrix metalloproteinases (MMPs), plasmin degrades extracellular matrix components, contributing to cancer metastasis and invasion (Beamish et al., 2019). Therefore, the activation of the uPA/uPAR system plays crucial roles in the induction of invasiveness and metastatic features in cancerous cells (Rubina et al., 2017). Rasouli et al. reported that treatment with Lactobacillus reuteri (L.reuteri), in AGS gastric cancer cells, downregulated the expression level of the uPA/uPAR gene (Rasouli et al., 2017). Table $\mathbf{1}$ provides a summary of studies on probiotics and gastric cancers. Nami et al. studied the anticancer effects of Lactobacillus plantarum species on human cancer cell lines (cervical, HeLa; gastric, AGS; colon, HT-29; and breast, MCF-7) and on a human normal cell line (HUVEC). The strain exhibited desirable probiotic properties and anticancer activity against the tested human cancer cell lines; no significant cytotoxic effects on normal cells were exhibited (Nami et al., 2014).

\section{Probiotics and Colon Cancer \\ Probiotics and Colon Cancer in Human Studies}

One of the important goals in treating colorectal cancer patients is improving their quality of life. The role of probiotics in decreasing the symptoms and improving the quality of life in colorectal cancer patients has been evaluated at different stages of the disease. Lacidofil supplementation for 12 weeks in patients with colorectal cancer reduced the frequency of bowel symptoms while promoted functional well-being scores compared with those of patients in the placebo group (Lee et al., 2014). Zonulin (haptoglobin 2 precursor) is a regulator of tight junctions and intestinal permeability in the wall of the digestive tract (Sturgeon and Fasano, 2016). The increased serum level of zonulin was associated with autoimmunity, inflammatory diseases, and gastrointestinal cancers (Mörkl et al., 2018). 
TABLE 1 | Probiotics and gastric cancer.

\begin{tabular}{|c|c|c|c|c|c|c|c|}
\hline Cancer cell line & Probiotic agent & $\begin{array}{c}\text { Probiotic } \\
\text { concentration }\end{array}$ & $\begin{array}{l}\text { Duration } \\
\text { of the } \\
\text { study }\end{array}$ & Effect (s) & Model & $\begin{array}{l}\text { Sample } \\
\text { (n) }\end{array}$ & Ref. \\
\hline AGS & Lactobacillus reuteri & $1.5 \times 10^{8} \mathrm{CFU} / \mathrm{ml}$ & $\begin{array}{l}24,48 \\
\text { and } 72 \mathrm{~h}\end{array}$ & $\begin{array}{l}\text { Inhibited cell proliferation and } \\
\text { decreased UPA and UPAR }\end{array}$ & In vitro & NA & $\begin{array}{l}\text { Rasouli et al. } \\
(2017)\end{array}$ \\
\hline HGC-27 & $\begin{array}{l}\text { Lactobacillus paracasei } \\
\text { IMPC2. } 1 \text { and Lactobacillus } \\
\text { rhamnosus GG }\end{array}$ & $1 \times 10^{8} \mathrm{CFU} / \mathrm{ml}$ & 24 or $48 \mathrm{~h}$ & $\begin{array}{l}\text { Induced apoptosis and } \\
\text { inhibited tumor growth }\end{array}$ & In vitro & NA & $\begin{array}{l}\text { Orlando et al. } \\
(2012)\end{array}$ \\
\hline $\mathrm{NCl}-\mathrm{N} 87$ and AGS & $\begin{array}{l}\text { Lactobacillus acidophilus } 74-2 \\
\text { and Bifidobacterium lactis } 420\end{array}$ & $\begin{array}{c}8.24 \times 10^{7} \text { and } 2.20 \times \\
10^{8} \mathrm{CFU} \text {, respectively }\end{array}$ & NA & $\begin{array}{l}\text { Upregulated the expression } \\
\text { of COX-1 }\end{array}$ & In vitro & NA & $\begin{array}{l}\text { Mahkonen } \\
\text { et al. (2008) }\end{array}$ \\
\hline HGC-27 & $\begin{array}{l}\text { Lactobacillus rhamnosus GG } \\
\text { (ATCC 53103) }\end{array}$ & $1 \times 10^{8} \mathrm{CFU} / \mathrm{ml}$ & 24 and $48 h$ & $\begin{array}{l}\text { Reduced the polyamine } \\
\text { content and neoplastic } \\
\text { proliferation }\end{array}$ & In vitro & NA & $\begin{array}{l}\text { Linsalata et al. } \\
\text { (2010) }\end{array}$ \\
\hline HGT-1 & $\begin{array}{l}\text { Propionibacterium } \\
\text { freudenreichii ITG P9 }\end{array}$ & $9 \times 10^{12} \mathrm{CFU} / \mathrm{ml}$ & $\begin{array}{l}24,48 \\
\text { or } 72 \mathrm{~h}\end{array}$ & $\begin{array}{l}\text { Induced caspase activation } \\
\text { and cytochrome } c \text { release }\end{array}$ & In vitro & NA & $\begin{array}{l}\text { Cousin et al. } \\
(2012)\end{array}$ \\
\hline AGS & $\begin{array}{l}\text { Lactobacillus fermentum UCO- } \\
\text { 979C and Lactobacillus casei } \\
\text { Shirota }\end{array}$ & $1.5 \times 10^{9} \mathrm{CFU} / \mathrm{ml}$ & $0-48 h$ & $\begin{array}{l}\text { Inhibited urease activity of } H \text {. } \\
\text { pylori }\end{array}$ & In vitro & NA & $\begin{array}{l}\text { Salas-Jara } \\
\text { et al. (2016) }\end{array}$ \\
\hline AGS & Lactobacillus plantarum 5BL & NA & $\begin{array}{l}12,24 \\
\text { and } 48 \mathrm{~h}\end{array}$ & $\begin{array}{l}\text { Induced anti-proliferative } \\
\text { effects and apoptosis }\end{array}$ & In vitro & NA & $\begin{array}{l}\text { Nami et al. } \\
(2014)\end{array}$ \\
\hline $\begin{array}{l}\text { Postoperative } \\
\text { patients with gastric } \\
\text { cancer }\end{array}$ & NA & NA & $7-8$ days & $\begin{array}{l}\text { Decreased the expression of } \\
\mathrm{IL}-6, \mathrm{IL}-8 \text {, and TNF- } \alpha\end{array}$ & Human & 70 & $\begin{array}{l}\text { Xie et al. } \\
(2018)\end{array}$ \\
\hline $\begin{array}{l}\text { Gastric cancer } \\
\text { patients }\end{array}$ & Bifidobacterium & NA & 4 weeks & $\begin{array}{l}\text { Decreased SIBO and } \\
\text { symptoms of gastric cancer } \\
\text { in the intervention group }\end{array}$ & Human & 112 & $\begin{array}{l}\text { Liang et al. } \\
(2016)\end{array}$ \\
\hline
\end{tabular}

UPA, urokinase-type plasminogen activator; UPAR, urokinase-type plasminogen activator receptor; COX-1, cyclooxygenase 1; H. pylori, Helicobacter pylori; IL-6, interleukin 6; IL-8, interleukin 8; TNF- $\alpha$, tumor necrosis factor alpha; SIBO, small intestine bacterial overgrowth.

Supplementation for 16 days (6 days preoperatively and 10 days postoperatively) with an admixture of $L$. plantarum, $L$. acidophilus-11, and B. longum-88 in colorectal cancer patients caused significant reduction in serum concentrations of zonulin as well as the duration of postoperative pyrexia, antibiotic therapy, and infectious complications in comparison with those in the placebo group. In addition, probiotic intervention inhibited the p38 mitogen-activated protein kinase signaling pathway (Liu et al., 2012). Yang and others reported that probiotic intervention with an admixture of $B$. longum, $L$. acidophilus, and Enterococcus faecalis (E. faecalis) for 12 days ( 5 days preoperatively and 7 days postoperatively) reduced the number of days to first defecation, days to first flatus, and diarrhea in the probiotic-treated group (Yang et al., 2016). 5Fluorouracil (5-FU) is one of the most effective drugs for chemotherapy in colorectal cancer patients (Fu et al., 2019). However, its use is associated with diarrhea (Cheng et al., 2020). In a recent study, 24-week supplementation with $L$. rhamnosus GG in colorectal cancer patients who received 5FU, the frequency of diarrhea was significantly decreased (Osterlund et al., 2007). Aisu et al. reported that supplementation with a probiotic mixture containing Enterococcus faecalis T110, Clostridium butyricum TO-A, and Bacillus mesentericus TO-A in colorectal cancer patients $(n=75)$ significantly diminished the occurrence of superficial incisional infection compared with that in untreated patients (Aisu et al., 2015). Fusobacterium is an important bacterial pathogen, which causes overexpression of E-cadherin $/ \beta$-catenin and subsequent colorectal cancer proliferation (Zhou et al., 2018). Using an admixture of B. longum, L. acidophilus, and Enterococcus faecalis (E. faecalis) in colorectal cancer patients $(n=11)$ for 5 days significantly altered mucosa-associated microbiota of the intestine. Furthermore, probiotic intervention reduced the secretion of taxon assigned to the Fusobacterium (Gao et al., 2015). The treatment of colorectal cancer patients $(n=84)$ with a combination of probiotics, which consisted of L. acidophilus, $L$. plantarum, B. lactis, and Saccharomyces boulardii (1 day preoperatively and 15 days postoperatively), significantly decreased pneumonia, surgical site infections, anastomosis leakage, and need for mechanical ventilation compared with those who did not receive probiotic supplementation (Kotzampassi et al., 2015). Other studies evaluating the properties of probiotics in colorectal cancer patients are summarized in Table 2.

\section{Probiotics and Colon Cancer in Animal Studies}

Probiotics exert their effects via activation or inhibition of cellular and molecular pathways (Figure 2). TNF- $\alpha$ is a proinflammatory cytokine which is produced by macrophages and $\mathrm{T}$-cells and has numerous immunological roles in the regulation of inflammation (Farajzadeh et al., 2017). Mi et al. reported that chemotherapy induced significant increases in the levels of interleukin-6 (IL-6), interleukin-1 beta (IL-1 $\beta$ ), and TNF- $\alpha$ expression in rats. In turn, treatment with Bifidobacterium infantis (B. infantis) decreased the level of the aforementioned cytokines. Furthermore, probiotic treatment reduced the expression of cytokines related to Th17 and Th1 cells, and these changes led to decreased chemotherapy-induced 
TABLE 2 | Probiotics and colon cancer in human studies.

\begin{tabular}{|c|c|c|c|c|c|c|}
\hline Subject & Probiotic agent & $\begin{array}{c}\text { Probiotic } \\
\text { concentration }\end{array}$ & $\begin{array}{l}\text { Duration of } \\
\text { the study }\end{array}$ & Effect (s) & $\begin{array}{l}\text { Sample } \\
\text { (n) }\end{array}$ & Ref. \\
\hline $\begin{array}{l}\text { Postoperative } \\
\text { patients with } \\
\text { colorectal cancer }\end{array}$ & $\begin{array}{l}\text { Lactobacillus acidophilus LA-5, } \\
\text { Lactobacillus plantarum, } \\
\text { Bifidobacterium lactis BB-12, } \\
\text { and Saccharomyces boulardii }\end{array}$ & $\begin{array}{c}1.75 \times 10^{9}, 0.5 \times \\
10^{9}, 1.75 \times 10^{9} \text {, and } \\
1.75 \times 10^{9} \mathrm{CFU} \text { per } \\
\text { capsule, respectively }\end{array}$ & $\begin{array}{l}16 \text { days ( } 1 \text { day prior } \\
\text { to operation and } \\
15 \text { days after } \\
\text { operation) }\end{array}$ & $\begin{array}{l}\text { Modulated the gene } \\
\text { expression of SOCS3 and } \\
\text { significantly decreased } \\
\text { postoperative complications } \\
\text { including mechanical } \\
\text { ventilation, infections, and } \\
\text { anastomotic leakage }\end{array}$ & 84 & $\begin{array}{l}\text { Kotzampassi } \\
\text { et al. (2015) }\end{array}$ \\
\hline Colorectal cancer & Bifidobacterium lactis & $1 \times 10^{9} \mathrm{CFU} / \mathrm{gr}$ & 4 weeks & $\begin{array}{l}\text { The amounts of IL-1 } 1 \beta \text {, IL-2, IL- } \\
12 \text {, and hs-CRP in the } \\
\text { probiotic group was } \\
\text { significantly lower than those } \\
\text { in symbiotic and prebiotic } \\
\text { intervention groups }\end{array}$ & 19 & $\begin{array}{l}\text { Worthley et al. } \\
\text { (2009) }\end{array}$ \\
\hline $\begin{array}{l}\text { Perioperative } \\
\text { patients with } \\
\text { colorectal cancer }\end{array}$ & $\begin{array}{l}\text { Bifidobacterium longum } \\
\text { (BB536) and Lactobacillus } \\
\text { johnsonii (La1) }\end{array}$ & $\begin{array}{c}2 \times 10^{7} \mathrm{CFU} / \mathrm{d} \text { and } 2 \times \\
10^{9} \mathrm{CFU} / \mathrm{d} \text { (two } \\
\text { separate doses) }\end{array}$ & $\begin{array}{l}8 \text { days ( } 3 \text { days before } \\
\text { operation and } 5 \text { days } \\
\text { after operation) }\end{array}$ & $\begin{array}{l}\text { The count of CD3, CD4, and } \\
\text { CD8 in both of the intervention } \\
\text { groups was greater than that } \\
\text { in the placebo group }\end{array}$ & $\begin{array}{l}11 \text { and } 10 \\
\text { (two } \\
\text { groups) }\end{array}$ & $\begin{array}{l}\text { Gianotti et al. } \\
(2010)\end{array}$ \\
\hline $\begin{array}{l}\text { Perioperative } \\
\text { patients with colon } \\
\text { cancer }\end{array}$ & Bifidobacterium bifidum & $1 \times 10^{10} \mathrm{CFU}$ & $\begin{array}{l}17 \text { days ( } 7 \text { days } \\
\text { before operation and } \\
10 \text { days after } \\
\text { operation) }\end{array}$ & $\begin{array}{l}\text { Surgical site infection in the } \\
\text { probiotic group significantly } \\
\text { decreased compared to that } \\
\text { in the antibiotic group }\end{array}$ & 100 & $\begin{array}{l}\text { Sadahiro et al. } \\
(2014)\end{array}$ \\
\hline Colorectal cancer & Bifidobacterium & NA & 4 weeks & $\begin{array}{l}\text { Decreased the symptoms of } \\
\text { colorectal cancer in the } \\
\text { intervention group }\end{array}$ & 88 & $\begin{array}{l}\text { Liang et al. } \\
\text { (2016) }\end{array}$ \\
\hline Colorectal cancer & $\begin{array}{l}\text { Lactobacillus rhamnosus } \\
\text { R0011 and Lactobacillus } \\
\text { acidophilus R0052 }\end{array}$ & $2 \times 10^{9} \mathrm{CFU}$ & 12 weeks & $\begin{array}{l}\text { Attenuated bowel symptoms } \\
\text { and improved quality of life in } \\
\text { colorectal cancer subjects }\end{array}$ & 28 & Lee et al. (2014) \\
\hline $\begin{array}{l}\text { Perioperative } \\
\text { patients with } \\
\text { colorectal and } \\
\text { colon cancer }\end{array}$ & $\begin{array}{l}\text { Bacillus natto and Lactobacillus } \\
\text { acidophilus }\end{array}$ & NA & 3 months & $\begin{array}{l}\text { In the colonic group, } \\
\text { defecation frequency, anal } \\
\text { pain, and the Wexner score } \\
\text { were significantly better than } \\
\text { those in patients in the rectal } \\
\text { cancer group }\end{array}$ & 77 & $\begin{array}{l}\text { Ohigashi et al. } \\
\text { (2011) }\end{array}$ \\
\hline $\begin{array}{l}\text { Perioperative } \\
\text { patients with } \\
\text { colorectal cancer }\end{array}$ & $\begin{array}{l}\text { Enterococcus faecalis T110, } \\
\text { Clostridium butyricum TO-A, } \\
\text { and Bacillus mesentericus } \\
\text { TO-A }\end{array}$ & $\begin{array}{c}2 \mathrm{mg}, 2 \mathrm{mg} \text {, and } \\
10 \mathrm{mg}, \text { respectively, } \\
\text { per each tablet }\end{array}$ & $\begin{array}{l}6-30 \text { days } \\
\text { ( } 3-15 \text { days prior to } \\
\text { and after the surgery) }\end{array}$ & $\begin{array}{l}\text { Enhanced the immune } \\
\text { responses and improved the } \\
\text { intestinal microbial } \\
\text { environment in the probiotic } \\
\text { group }\end{array}$ & 75 & $\begin{array}{l}\text { Aisu et al. } \\
(2015)\end{array}$ \\
\hline Healthy subjects & $\begin{array}{l}\text { Bifidobacterium longum } \\
\text { (BB536-y) }\end{array}$ & NA & 5 weeks & $\begin{array}{l}\text { Inhibited colorectal } \\
\text { carcinogenesis }\end{array}$ & 14 & $\begin{array}{l}\text { Ohara and } \\
\text { Suzutani, } \\
\text { (2018) }\end{array}$ \\
\hline Colorectal cancer & $\begin{array}{l}\text { Lactobacillus acidophilus and } \\
\text { Lactobacillus plantarum }\end{array}$ & NA & NA & $\begin{array}{l}\text { Reduced the severity of } \\
\text { colorectal cancer }\end{array}$ & 25 & $\begin{array}{l}\text { Zinatizadeh } \\
\text { et al. (2018) }\end{array}$ \\
\hline $\begin{array}{l}\text { Perioperative } \\
\text { patients with } \\
\text { colorectal cancer }\end{array}$ & $\begin{array}{l}\text { Bifidobacterium longum, } \\
\text { Lactobacillus acidophilus, and } \\
\text { Enterococcus faecalis }\end{array}$ & $\begin{array}{l}0.21 \mathrm{gr}\left(1 \times 10^{8} \mathrm{CFU} /\right. \\
\mathrm{gr}) \text { in each capsule }\end{array}$ & $\begin{array}{l}3 \text { days before } \\
\text { operation }\end{array}$ & $\begin{array}{l}\text { Promoted the expression } \\
\text { levels of IgG and slgA, while } \\
\text { diminished the IL- } 6 \text { and CRP } \\
\text { serum in the intervention } \\
\text { group }\end{array}$ & 30 & $\begin{array}{l}\text { Zhang et al. } \\
\text { (2012) }\end{array}$ \\
\hline $\begin{array}{l}\text { Perioperative } \\
\text { patients with } \\
\text { colorectal cancer }\end{array}$ & $\begin{array}{l}\text { Lactobacillus acidophilus, } \\
\text { Lactobacillus casei, } \\
\text { Lactobacillus lactis, } \\
\text { Bifidobacterium bifidum, } \\
\text { Bifidobacterium longum, and } \\
\text { Bifidobacterium infantis }\end{array}$ & $3 \times 10^{10} \mathrm{CFU}$ & $\begin{array}{l}7 \text { days before } \\
\text { operation }\end{array}$ & $\begin{array}{l}\text { Hospital stay duration in the } \\
\text { probiotic-administrated } \\
\text { patients was shorter than that } \\
\text { of the patients in the placebo } \\
\text { group }\end{array}$ & 20 & $\begin{array}{l}\text { Tan et al. } \\
(2016)\end{array}$ \\
\hline Colorectal cancer & $\begin{array}{l}\text { Bifidobacterium longum, } \\
\text { Lactobacillus acidophilus, and } \\
\text { Enterococcus faecalis }\end{array}$ & $6 \times 10^{7} \mathrm{CFU}$ & 5 days & $\begin{array}{l}\text { Probiotic treatment altered the } \\
\text { mucosal microbial flora }\end{array}$ & 11 & $\begin{array}{l}\text { Gao et al. } \\
(2015)\end{array}$ \\
\hline $\begin{array}{l}\text { Perioperative } \\
\text { patients with } \\
\text { colorectal cancer }\end{array}$ & $\begin{array}{l}\text { Lactobacillus plantarum, } \\
\text { Lactobacillus acidophilus, and } \\
\text { Bifidobacterium longum }\end{array}$ & $\begin{array}{c}2 \mathrm{~g} \text { day in a } \\
\text { concentration of } 2.6 \times \\
10^{14} \mathrm{CFU}\end{array}$ & $\begin{array}{l}16 \text { days ( } 6 \text { days } \\
\text { preoperatively and } \\
10 \text { days } \\
\text { postoperatively) }\end{array}$ & $\begin{array}{l}\text { Probiotic treatment } \\
\text { upregulated the mucosal tight } \\
\text { junction protein expression }\end{array}$ & 50 & $\begin{array}{l}\text { Liu et al. } \\
\text { (2011a) }\end{array}$ \\
\hline $\begin{array}{l}\text { Patients with } \\
\text { colorectal tumors }\end{array}$ & Lactobacillus casei Shirota & $1 \times 10^{10} \mathrm{CFU} / \mathrm{gr}$ & 4 years & $\begin{array}{l}\text { Occurrence of tumors much } \\
\text { significantly decreased in }\end{array}$ & 99 & $\begin{array}{l}\text { Ishikawa et al. } \\
(2005)\end{array}$ \\
\hline
\end{tabular}


TABLE 2 | (Continued) Probiotics and colon cancer in human studies.

\begin{tabular}{|c|c|c|c|c|c|c|}
\hline Subject & Probiotic agent & $\begin{array}{c}\text { Probiotic } \\
\text { concentration }\end{array}$ & $\begin{array}{l}\text { Duration of } \\
\text { the study }\end{array}$ & Effect (s) & $\begin{array}{l}\text { Sample } \\
\text { (n) }\end{array}$ & Ref. \\
\hline & & & & $\begin{array}{l}\text { probiotic-administrated } \\
\text { subjects compared with that } \\
\text { in other groups }\end{array}$ & & \\
\hline $\begin{array}{l}\text { Perioperative } \\
\text { patients with } \\
\text { colorectal cancer }\end{array}$ & $\begin{array}{l}\text { Bifidobacterium longum, } \\
\text { Lactobacillus acidophilus, and } \\
\text { Enterococcus faecalis }\end{array}$ & $\geq 3 \times 10^{7} \mathrm{CFU} / \mathrm{gr}$ & $\begin{array}{l}12 \text { days ( } 5 \text { days } \\
\text { preoperatively and } \\
7 \text { days } \\
\text { postoperatively) }\end{array}$ & $\begin{array}{l}\text { The incidence of diarrhea in } \\
\text { the probiotic group was lower } \\
\text { than that in the placebo group }\end{array}$ & 30 & $\begin{array}{l}\text { Yang et al. } \\
(2016)\end{array}$ \\
\hline $\begin{array}{l}\text { Perioperative } \\
\text { patients with } \\
\text { colorectal cancer }\end{array}$ & $\begin{array}{l}\text { Lactobacillus plantarum, } \\
\text { Lactobacillus acidophilus } \\
\text { 11,and Bifidobacterium } \\
\text { longum } 88\end{array}$ & $2.6 \times 10^{14} \mathrm{CFU}$ & $\begin{array}{l}16 \text { days ( } 6 \text { days } \\
\text { preoperatively and } \\
10 \text { days } \\
\text { postoperatively) }\end{array}$ & $\begin{array}{l}\text { Treatment with the probiotic } \\
\text { decreased the infection rate, } \\
\text { serum zonulin concentration, } \\
\text { and duration of antibiotic } \\
\text { therapy }\end{array}$ & 75 & Liu et al. (2012) \\
\hline Healthy subjects & $\begin{array}{l}\text { Lactobacillus rhamnosus } \\
\text { LC705 and Propionibacterium } \\
\text { freudenreichii ssp. shermanii JS }\end{array}$ & $\begin{array}{c}4 \times 10^{10} \mathrm{CFU}(2 \times \\
10^{10} \mathrm{CFU} \text { of each strain } \\
\text { per day })\end{array}$ & 4 weeks & $\begin{array}{l}\text { Probiotic supplementation } \\
\text { decreased the activity of } \\
\beta \text {-glucosidase }\end{array}$ & 37 & $\begin{array}{l}\text { Hatakka et al. } \\
\text { (2008) }\end{array}$ \\
\hline
\end{tabular}

SOCS3 suppressor of cytokine signaling 3; IL-1ß, interleukin 1 beta; IL-2, interleukin 2; IL-12, interleukin 12; hs-CRP, high-sensitivity C-reactive protein; IgG, immunoglobulin G; slgA, sensitive immunoglobulin A; CRP, C-reactive protein.

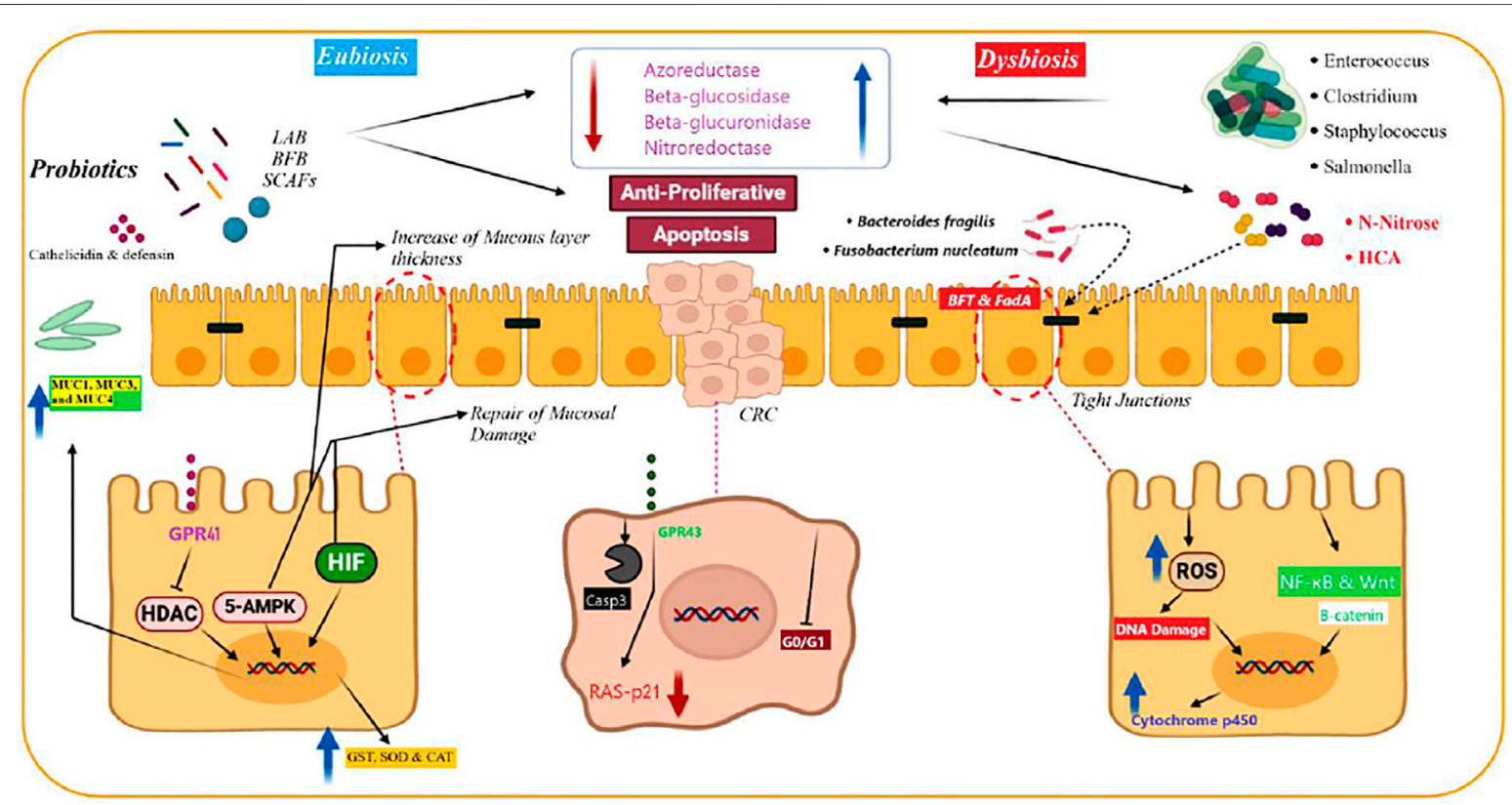

FIGURE 2 | Physiological nonspecific mechanisms of probiotics for preventing and treating colorectal cancer (CRC). Probiotics produce short-chain fatty acid (SCFA) and mediate apoptotic and anti-proliferative reactions in CRC cells. Produced SCAFs by probiotics protect the intestinal tract by preventing the histone deacetylases (HDACs) and overexpression of mucins, including MUC1, MUC3, and MUC4. SCFAs activate 5'-adenosine monophosphate-activated protein kinase. This is a critical factor in keeping the hypoxia-inducible factor via SCAFs, which improves the epithelial duct's survival and function. Probiotics elevate antimicrobial peptides, including defensin and (LL-37) cathelicidin, from the intestinal mucosal layer. These peptides protect them against bacterial inoculation and invasion. Probiotics inhibit enzymatic activity of pathogenic bacteria, including enzymes such as nitroreductase, $\beta$-glucuronidase, azoreductase, and $\beta$-glucosidase. They also decrease the production of carcinogenic agents. Probiotics inhibit carcinogenic agents ( $\mathrm{N}$-nitrous and heterocyclic aromatic amines [HCA]) by two mechanisms (deactivation and binding). They are potent mutagens and result in carcinogenic mutations in intestinal cells. Moreover, probiotics increase the antioxidant enzyme production and inactivate carcinogen-deactivating agents, including glutathione reductase, glutathione-S-transferase (GST), superoxide dismutase (SOD), glutathione peroxidase, and catalase (CAT), and decrease their adverse effects. Besides, probiotics eliminate the risk of CRC development due to metabolites that have effects on the cytochrome p450. This figure is adapted from Eslami et al., (2019).

mucositis (Mi et al., 2017). Ras-p21 is an oncoprotein and plays critical roles in the induction of different cancers (BanysPaluchowski et al., 2018). In rats with azoxymethane-induced colorectal cancer, Bifidobacterium longum (B. longum) administration significantly suppressed the tumor volume, tumor incidence, cell proliferation, and the expression of ras- 
p21 (Singh et al., 1997). Administration of L. plantarum and $L$. rhamnosus promoted the expression of anti-oxidant enzymes such as glutathione, superoxide dismutase, catalase, glutathione reductase, glutathione peroxidase, and glutathione-S-transferase in rats with 1,2-dimethylhydrazine-induced colorectal cancer. Furthermore, the treatment increased the concentrations of pro-apoptotic agents, such as p53, B-cell lymphoma 2 (Bcl-2), BCL2-associated X (Bax), caspase-9, and caspase-3, which are involved in the p53-mediated apoptotic pathway (Walia et al., 2018). Walia and others demonstrated that 16-week supplementation with L. plantarum and L. rhamnosus decreased the expression of cyclooxygenase-2 (COX-2). Therefore, it appears that suppressing COX-2 is a potential protective mechanism against colon cancer development, leading to decreased tumor volume and incidence (Walia et al., 2015). Ki-67 is a tumor proliferative marker that is associated with the upper proliferation rate in various types of cancers (Sun and Kaufman, 2018). An admixture of L. fermentum and $L$. acidophilus in the mouse model of colorectal cancer reduced tumor growth, survival, and proliferation and decreased the expression of Ki-67 compared with those of the placebo group. Concomitantly, probiotic supplementation had no significant effects on the expression of cleaved caspase-3, E-cadherin, and $\beta$-catenin in comparison with that of the other group (Kahouli et al., 2017). In the dimethylhydrazineinduced colon cancer model, the probiotic strain L. rhamnosus GG suppressed the expression of $\beta$-catenin, COX-2, and TNF- $\alpha$. Moreover, probiotic supplementation upregulated the expression of pro-apoptotic proteins Bax, $\mathrm{p} 53$, and caspase 3 and downregulated the expression of $\mathrm{Bcl}-2$ as an anti-apoptotic agent (Kumar et al., 2012). Agah and others compared the efficacy of $L$. acidophilus and B. bifidum probiotic strains against the azoxymethane-induced mouse model of colon cancer. The results showed that the colonic lesions incidence was decreased after probiotic intervention compared with that of the control group, and these effects were more potent for $L$. acidophilus than for B. bifidum. Serum concentrations of tumor markers CEA and CA19-9 were reduced after treatment with probiotics, while the expression of interferon gamma (IFN- $\gamma$ ), interleukin-10(IL-10), and the count of $\mathrm{CD} 4^{+}$and $\mathrm{CD} 8^{+}$cells were upregulated upon intervention (Agah et al., 2019a). Wang et al. evaluated the efficacy of 12-week probiotic VSL\#3 supplementation on azoxymethane/dextran sulfate sodiuminduced colitis-associated carcinogenesis $\left(1.5 \times 10^{9} \mathrm{CFU}\right)$. Compared with that of the untreated group, probiotic supplementation downregulated the expression level of IL-6 and TNF- $\alpha$ in a considerable manner. Furthermore, probiotic intervention decreased the Oscillibacter and Lachnoclostridium genera, coupled with increased presence of Bacillus and Lactococcus genera in the fecal microbial composition of mice samples (Wang et al., 2018a). The c-Jun $\mathrm{NH}_{2}$-terminal kinase (JNK) is a major protein kinase which belongs to the MAPK signaling pathway and plays pivotal functions in the regulation of cell proliferation, cell death, apoptosis, and other features of cancerous cells (Wu et al., 2019). Considering its interfering role in different molecular pathways including NF-kB, JNK has binary roles in cancer development/progression (Tournier,
2013). By inhibiting the phosphorylation of glycogen synthase kinase 3 beta (GSK3 $\beta$ ), JNK has suppressive effects on the expression of $\beta$-catenin ( $\mathrm{Hu}$ et al., 2009). Ali et al. reported that $L$. casei probiotic supplementation in mice with 1,2dimethylhydrazine-induced colon cancer significantly reduced the number of aberrant crypt foci compared with that in untreated animals. Furthermore, by upregulating the expression of phosphorylated JNK-1, L. casei regulated the expression of $\beta$-catenin and phosphorylated GSK3 $\beta$, leading to significant protective effects against colon cancer (Ali et al., 2019). Sakatani and others have demonstrated that a L. brevis-derived polyphosphate significantly promoted the activation of the ERK signaling pathway, expression of cleaved PARP, and the ratio of cleaved PARP/PARP in SW620 colon cancer cells and mice bearing SW620 tumor xenografts. These changes led to increased apoptosis and inhibition of colon cancer growth (Sakatani et al., 2016a). By increasing the level of various inflammatory cytokines including IL-18, TNF- $\alpha$, and TGF- $\beta 1$, the NLR family pyrin domain-containing 3 (NLRP3) inflammasome can trigger metastasis in colon and colorectal cancer samples (Shaima'a Hamarsheh, 2020). The results of a recent study demonstrated that probiotic supplementation with the $E$. faecalis strain caused inhibitory effects on the activation of caspase-1 and maturation of IL-1 $\beta$ in vivo. Furthermore, E. faecalis suppressed the activation of NLRP3 inflammasome, and thereby protected animals from intestinal inflammation in dextran sodium sulfate-induced colitis-associated colorectal cancer (Chung et al., 2019a). Two-week intervention with $L$. casei in 1,2-dimethylhydrazine dihydrochloride-induced colon cancer in mice reduced the occurrence of chemical-induced aberrant crypt foci and the activity of ornithine decarboxylase. As noted previously, by promoting the polyamine metabolism in tumoral cells, ornithine decarboxylase has a pivotal function in the induction of cell proliferation. Hence, suppression of this enzyme in vivo diminished colon cancer growth and proliferation (Irecta-Nájera et al., 2017a). Numerous investigations have demonstrated that the expression level of insulin-like growth factor-1 (IGF-1) and IGF-1 receptor (IGF$1 \mathrm{R})$ in colorectal cancer patients is associated with poor prognosis, chemoresistance, and increased invasiveness features (Shiratsuchi et al., 2011; Vigneri et al., 2015). Valadez-Bustos and others demonstrated that probiotic intervention with B. longum BAA-999 in the colorectal murine model reduced the expression level and activity of IGF-1/IGF-1R in a considerable manner. Furthermore, after probiotic supplementation, the expression level of insulin-like growth factor-binding protein-3 (IGFBP3) was normalized. Overall, the noted alterations led to reduction in the tumor volume and size (Valadez-Bustos et al., 2019). In a comprehensive in vivo investigation, Jacouton and others found that by decreasing the expression grade of IL-22 as a pro-inflammatory cytokine and upregulating the expression of caspase-7, caspase-9, and Bik, probiotic treatment with $L$. casei BL23 had significant anti-proliferative effects in the azoxymethane-induced colorectal cancer model (O'Mahony et al., 2001). Table 3 provides a summary of in vivo investigations on the efficacy of probiotics in colorectal cancers. 
TABLE 3 | Probiotics and colon cancer in animal studies.

\begin{tabular}{|c|c|c|c|c|}
\hline Probiotic agent & Probiotic concentration & $\begin{array}{l}\text { Duration } \\
\text { of the study }\end{array}$ & Effect (s) & Ref. \\
\hline Bifidobacterium longum BAA-999 & $8.992 \times 10^{10} \mathrm{CFU} / \mathrm{ml}$ & 16 weeks & $\begin{array}{l}\text { Regulated IGF-1, IGF-1R, and IGFBP3 } \\
\text { protein expressions }\end{array}$ & $\begin{array}{l}\text { Valadez-Bustos et al. } \\
\text { (2019) }\end{array}$ \\
\hline VSL\#3 & $1.5 \times 10^{9} \mathrm{CFU}$ & $\begin{array}{l}3 \text { months ( } 5 \text { days } \\
\text { weekly) }\end{array}$ & $\begin{array}{l}\text { The level of TNF- } \alpha \text { and IL- } 6 \text { was reduced } \\
\text { in colon tissue and tumor load after } \\
\text { probiotic intervention }\end{array}$ & Wang et al. (2018b) \\
\hline VSL\#3 & $10^{9} \mathrm{CFU}$ daily & 18 weeks & Altered the microbial composition & Arthur et al. (2013) \\
\hline Lactobacillus plantarum & $1 \times 10^{9} \mathrm{CFU} / \mathrm{ml}$ & 8 months & $\begin{array}{l}\text { Reduced } \beta \text {-galactosidase and } \\
\beta \text {-glucuronidase activities. Besides, } \\
\text { reduced the number of total coliforms }\end{array}$ & Čokášová et al. (2012) \\
\hline Lactobacillus casei strain Shirota & $2.1 \times 10^{10}$ & $\begin{array}{l}8,12, \text { and } \\
25 \text { weeks }\end{array}$ & $\begin{array}{l}\text { Significantly inhibited aberrant crypt foci } \\
\text { and colon carcinogenesis }\end{array}$ & Yamazaki et al. (2000) \\
\hline $\begin{array}{l}\text { Lactobacillus fermentum and } \\
\text { Lactobacillus plantarum }\end{array}$ & $\begin{array}{c}2 \times 10^{8} \mathrm{CFU} / \mathrm{g} \text { and } 2 \times \\
10^{8} \mathrm{CFU} / \mathrm{g}\end{array}$ & 21 days & $\begin{array}{l}\text { Decreased the number of crypts in the } \\
\text { mice and the activities of } \beta \text {-galactosidase } \\
\text { and } \beta \text {-glucuronidase }\end{array}$ & $\begin{array}{l}\text { Asha and Gayathri, } \\
\text { (2012) }\end{array}$ \\
\hline VSL\#3 & $1.3 \times 10^{6} \mathrm{CFU}$ & 44 days & $\begin{array}{l}\text { Protected against carcinogenesis } \\
\text { through regulating the IL-6/STAT3 } \\
\text { signaling pathway }\end{array}$ & Do et al. (2016) \\
\hline Saccharomyces boulardii & $\begin{array}{c}3 \times 10^{8} \mathrm{CFU} / \mathrm{ml} \text { and } 6 \times \\
10^{8} \mathrm{CFU} / \mathrm{ml}\end{array}$ & 9 weeks & $\begin{array}{l}\text { Suppressed HER-2, HER-3, IGF-1R, } \\
\text { EGFR-Erk, and EGFR-Akt expression } \\
\text { levels and intestinal tumor growth }\end{array}$ & Chen et al. (2009) \\
\hline $\begin{array}{l}\text { Lactobacillus delbrueckii subsp. } \\
\text { bulgaricus and Streptococcus } \\
\text { thermophilus }\end{array}$ & less than $1 \times 10^{2} \mathrm{CFU} / \mathrm{ml}$ & 5 months & $\begin{array}{l}\text { Reduced } \beta \text {-glucuronidase and } \\
\text { nitroreductase activity }\end{array}$ & $\begin{array}{l}\text { de Moreno de LeBlanc } \\
\text { and Perdigón, (2005) }\end{array}$ \\
\hline Lactobacillus casei ATCC 393 & $10^{6} \mathrm{CFU}$ & 2 weeks & $\begin{array}{l}\text { Showed protective effects against } \\
\text { ornithine decarboxylase activities }\end{array}$ & $\begin{array}{l}\text { Irecta-Nájera et al. } \\
(2017 b)\end{array}$ \\
\hline $\begin{array}{l}\text { Lactobacillus acidophilus and } \\
\text { Lactobacillus rhamnosus GG }\end{array}$ & $1 \times 10^{9}$ lactobacilli/0.1 ml & 18 weeks & $\begin{array}{l}\text { Caused decrease in Bcl-2 and K-ras and } \\
\text { increase in Bax and p53 expression } \\
\text { levels. Promoted Bax-mediated } \\
\text { apoptosis in colon carcinogenesis }\end{array}$ & Sharaf et al. (2018) \\
\hline $\begin{array}{l}\text { Lactobacillus rhamnosus GG MTCC } \\
\# 1408, \text { Lactobacillus casei MTCC \#1423, } \\
\text { and Lactobacillus plantarum MTCC } \\
\# 1407\end{array}$ & $1 \times 10^{9} \mathrm{CFU} / 0.1 \mathrm{ml}$ & 7 weeks & $\begin{array}{l}\text { Probiotic administration decreased the } \\
\text { activity of } \beta \text {-glucosidase }\end{array}$ & $\begin{array}{l}\text { Verma and Shukla, } \\
\text { (2013) }\end{array}$ \\
\hline Lactobacillus casei BL23 & $5 \times 10^{9} \mathrm{CFU} / \mathrm{ml}$ & 53 days & $\begin{array}{l}\text { Decreased the expression of IL-22 while } \\
\text { increased the expression of caspase- } 7 \text {, } \\
-9 \text {, and Bik }\end{array}$ & Jacouton et al. (2017) \\
\hline $\begin{array}{l}\text { Lactobacillus salivarius ssp. salivarius } \\
\text { UCC118 }\end{array}$ & NA & 16 weeks & $\begin{array}{l}\text { Reduced the number of fecal coliform and } \\
\text { enterococci levels }\end{array}$ & O'Mahony et al. (2001) \\
\hline Enterococcus faecium CRL 183 & NA & 42 weeks & $\begin{array}{l}\text { Increased the immune response by } \\
\text { promoting the expression of } \mathrm{NO}, \mathrm{IL}-4 \text {, } \\
\mathrm{IFN}-\gamma \text {, and TNF- } \alpha\end{array}$ & Sivieri et al. (2008) \\
\hline $\begin{array}{l}\text { Lactobacillus acidophilus LaVK2 and } \\
\text { Bifidobacterium bifidum BbVK3 }\end{array}$ & $\begin{array}{c}2 \times 10^{9} \mathrm{CFU} / \mathrm{g} \text { of each } \\
\text { strain }(20 \mathrm{~g})\end{array}$ & 32 weeks & $\begin{array}{l}\text { Probiotics decreased the pre-neoplastic } \\
\text { lesions and PCNA expression level }\end{array}$ & Mohania et al. (2014) \\
\hline VSL\#3 & $333 \times 10^{9} \mathrm{CFU} / \mathrm{g}$ & 115 days & $\begin{array}{l}\text { Promoted angiostatin, VDR, and alkaline } \\
\text { sphingomyelinase expression }\end{array}$ & Appleyard et al. (2011) \\
\hline $\begin{array}{l}\text { Bifidobacterium longum, Lactobacillus } \\
\text { acidophilus, and Enterococcus faecalis }\end{array}$ & $1 \times 10^{7} \mathrm{CFU}$ of each & 9 weeks & $\begin{array}{l}\text { Alleviated colitis through regulating } \\
\text { CXCR2 signaling }\end{array}$ & Song et al. (2018) \\
\hline Enterococcus faecalis $\mathrm{KH} 2$ & $17 \mathrm{mg} / \mathrm{kg}$ & 2 weeks & $\begin{array}{l}\text { Modulated the activity of the NLRP3 } \\
\text { inflammasome and ameliorated colitis- } \\
\text { associated colorectal cancer }\end{array}$ & Chung et al. (2019b) \\
\hline $\begin{array}{l}\text { B. bifidum (Bla/016P/M) and Lactobacillus } \\
\text { acidophilus }\end{array}$ & $1 \times 10^{9} \mathrm{CFU} / \mathrm{g}$ of each strain & $\begin{array}{l}10 \text { days before } \\
\text { tumor induction and } \\
5 \text { months after it }\end{array}$ & $\begin{array}{l}\text { IFN- } \gamma \text { and IL-10 serum levels and the } \\
\text { number of } \mathrm{CD} 4^{+} \text {and } \mathrm{CD} 8^{+} \text {cells were } \\
\text { decreased after probiotic administration }\end{array}$ & Agah et al. (2019b) \\
\hline $\begin{array}{l}\text { Lactobacillus acidophilus, Lactobacillus } \\
\text { rhamnosus, and Bifidobacterium bifidum }\end{array}$ & $0.6 \times 10^{6} \mathrm{CFU}$ of each strain & 1 week & $\begin{array}{l}\text { Reduced the expression of RANTES, } \\
\text { eotaxin, p-IKK, and TNF- } \alpha \text { while } \\
\text { increased IL-10 expression }\end{array}$ & Mendes et al. (2018) \\
\hline Lactobacillus salivarius Ren & $5 \times 10^{8}$ and $1 \times 10^{10} \mathrm{CFU} / \mathrm{kg}$ & 2 weeks & $\begin{array}{l}\text { Prevented carcinogenesis by regulating } \\
\text { the intestinal microflora }\end{array}$ & Zhu et al. (2014) \\
\hline $\begin{array}{l}\text { Lactobacillus rhamnosus GG CGMCC } \\
1.2134\end{array}$ & $1 \times 10^{9} \mathrm{CFU} / 1 \mathrm{ml}$ & 25 weeks & $\begin{array}{l}\beta \text {-catenin, Bcl- } 2, \text { NFkB-p65, COX-2, and } \\
\text { TNF- } \alpha \text { expression levels were decreased } \\
\text { after probiotic intervention }\end{array}$ & Gamallat et al. (2016) \\
\hline Lactobacillus plantarum AS1 & $10^{9} \mathrm{CFU} / \mathrm{ml}$ & 26 weeks & $\begin{array}{l}\text { Had antioxidant-induced prevention of } \\
\text { colon carcinogenesis }\end{array}$ & Kumar et al. (2012) \\
\hline
\end{tabular}

(Continued on following page) 
TABLE 3 | (Continued) Probiotics and colon cancer in animal studies.

Probiotic agent Probiotic concentration

\section{of the study}

Lactobacillus casei Zhang

Lactobacillus casei BL23 and

Lactococcus lactis MG1363

Bacillus subtilis-SKm (KFCC11520P) and Lactococcus lactis-GAm (KFCC11510P)

VSL\#3

Propionibacterium freudenreichii TL133

VSL\#3

Lactobacillus acidophilus and

Bifidobacterium animalis subsp. lactis and

both of them

Lactobacillus acidophilus

Streptococcus thermophilus CRL807 and

Lactobacillus delbrueckii subsp.

bulgaricus CRL864

Lactobacillus plantarum (AdF10) and

Lactobacillus rhamnosus GG (LGG)

VSL\#3

Lactobacillus acidophilus

Lactobacillus plantarum (AdF10) and

Lactobacillus rhamnosus GG (LGG)

Lactobacillus acidophilus CL1285,

Lactobacillus casei LBC80R, and

Lactobacillus rhamnosus CLR2

Lactobacillus plantarum A and

Lactobacillus rhamnosus b

Streptococcus thermophilus CRL807,

Streptococcus thermophilus CRL807,

Streptococcus thermophilus CRL807,

Lactococcus lactis subsp. cremoris

MG1363, Lactococcus lactis subsp.

cremoris MG1363, and Lactococcus

lactis subsp. cremoris MG1363

Lactobacillus acidophilus (NCK 2025)

Lactobacillus acidophilus (Delvo Pro LA-

1), Lactobacillus rhamnosus (GG),

Bifidobacterium animalis (CSCC 1941),

and Streptococcus thermophilus (DD145)

Bifidobacterium longum

Bifidobacterium adolescentis SPM0212
$4 \times 10^{9} \mathrm{CFU}$

$4 \times 10^{9} \mathrm{CFU}$
$1 \pm 0.4 \times 10^{9} \mathrm{CFU} /$ mouse
$10^{6} \mathrm{CFU} / \mathrm{g}$ of Bacillus subtilis-
$\mathrm{SKm}$ and $10^{6} \mathrm{CFU} / \mathrm{g}$ of
Lactococcus lactis-GAm
$333 \times 10^{9} \mathrm{CFU} / \mathrm{g}$
$2 \times 10^{10} \mathrm{CFU} / \mathrm{ml}$
$1.2 \times 10^{9}$ bacteria per day
$5 \times 10^{7} \mathrm{CFU} / \mathrm{g}$ and $5 \times$
$10^{7} \mathrm{CFU} / \mathrm{g}$ and both strains
$\left(2.5 \times 10^{7} \mathrm{CFU} / \mathrm{g}\right.$ for each
strain)
$10^{10} \mathrm{CFU} / \mathrm{ml}$

NA

6 months

4 weeks

18 days

32 days

10 weeks

CFU/m

NA

5 days

$1 \times 10^{10} \mathrm{CFU}$

16 weeks

$1.3 \times 10^{6}$ bacteria

8 weeks

$2 \times 10^{8} \mathrm{CFU} / \mathrm{ml}$

1 month

$10^{10} \mathrm{CFU} / \mathrm{ml}$

16 weeks

At least $50 \times 10^{9} \mathrm{CFU} / \mathrm{g}$ of 12 weeks strains

$1 \times 10^{8}$ CFU for 14 consecutive 5 weeks days, then $1 \times 10^{9} \mathrm{CFU}$ for 3 weeks

$$
1 \times 10^{10} \mathrm{CFU} / \mathrm{ml} \quad 6 \text { months }
$$

Effect (s)

Suppressed tumorigenesis through modulating various adiponectin-elevated signaling pathways

Along with the modulation of regulatory

T-cells, promoted the expression of IL-6, IL-17, IL-10, and TGF- $\beta$

Probiotics decreased the expression of iNOS, COX-2, and Bcl-2 while increased Bax, p21, and p53 expression levels

Reduced the expression of TNF- $\alpha, \mathrm{IL}-1 \beta$, Talero et al. (2015) IL-6, and COX-2 while increased IL-10 expression Increased the induction of apoptosis Increased the expression of TNF- $\alpha$, angiostatin, IL-17, and PPAR- $\gamma$ Increased the expression of caspase-3 and decreased the expression of $\mathrm{Bcl}-2$

Adenomas have been reported to be decreased after probiotic administration Prevented colitis and carcinogenesis via modulating anti-inflammatory responses

Regulated COX-2 expression

Diminished the severity of colitis and tumor growth

Attenuated COX-2, iNOS, and c-Myc expression levels

Had chemopreventive effects

Decreased the activity of $\beta$-glucosidase and $\beta$-glucuronidase along with the reduction in aberrant crypt foci counts Increased production of IFN- $\gamma$ and promoted Th1-type $\mathrm{CD}^{+}{ }^{+} \mathrm{T}$ differentiation

Exerted anti-tumorigenic properties via increasing antioxidant enzymes and IL-10 expression level
Ref.

Zhang et al. (2017)

Lenoir et al. (2016)

Jeong et al. (2012)

Lan et al. (2008)

Bassaganya-Riera et al. (2012)

Lin et al. (2019)

Urbanska et al. (2009)

Del Carmen et al. (2016)

Walia et al. (2015)

Deol et al. (2018)

Walia et al. (2018)

Desrouillères et al. (2015)

Hu et al. (2015a)

Del Carmen et al. (2017)
Chung et al. (2017) 


\section{Probiotics and Colon Cancer in In Vitro Studies}

As mentioned earlier, caspase- 3 is a pro-apoptotic factor and its decreased levels are associated with the shortened survival time in various types of cancers (Vince et al., 2018). Bacillus coagulans (B. coagulans) Unique IS2 exerted anti-proliferative and proapoptotic properties in the COLO 205 human colon cancer cell line. By activating the p-53-mediated apoptotic pathway, treatment with probiotics increased the expression of BAX, activation of caspase-3, cleavage of poly (ADP-ribose) polymerase, and release of cytochrome $C$. Furthermore, $B$. coagulans reduced the mitochondrial membrane potential and Bcl 2 expression level (Madempudi and Kalle, 2017). Orlando and others reported that L. rhamnosus GG intervention in Caco-2, HT-29, and SW480 colon cancer cell lines upregulated the Bax/ Bcl-2 ratio, increasing apoptosis in these cells (Orlando et al., 2016). The cyclin family is a group of cell cycle regulators. Their aberrant expression is associated with tumorigenesis (Wood and Endicott, 2018). Intervention with $L$. paracasei subsp. paracasei reduced the expressions of cyclin D1 and cyclin E1 X12 in HT-29 colon cancer cells. In addition, probiotic intervention upregulated the expression of p27 as a cyclin-dependent kinase (CDK) inhibitor (Huang et al., 2016). CKD inhibition represents a potential mechanism for suppressing over proliferation of cancer cells induced by aberrant regulation of the cyclin family (Sánchez-Martínez et al., 2019). PTEN (phosphatase and tensin homolog) has been demonstrated to be a prominent tumor suppressor gene, which plays critical roles in the dephosphorylation of phosphatidylinositol 3,4,5-trisphosphate (PIP3) (Di Cristofano et al., 1998). The additional evidence indicated that downregulation of PTEN is associated with increased tumor growth and survival. Therefore, targeting PTEN inhibitors is one of the most effective means for decreasing the tumor incidence, tumor volume, and tumor growth rate (Lee et al., 2019a). Sambrani et al. demonstrated, in HT-29 colon cancer cells, that treatment with Saccharomyces cerevisiae (S. cerevisiae) caused a significant upregulation in the expression of PTEN and caspase-3, while the expression levels of Bcl-xL and RelA were markedly decreased after probiotic intervention (Sambrani et al., 2019). Pichia kudriavzevii AS-12 treatment showed considerable cytotoxic properties in HT-29 and Caco- 2 cells compared with those in normal control cells. In addition, Pichia kudriavzevii upregulated the expression of proapoptotic agents including Fas-R, caspase-3, -8, and -9, and BAD protein, while the expression of anti-apoptotic Bcl-2 was decreased after yeast probiotic treatment in mentioned cell lines (Saber et al., 2017). Bacillus polyfermenticus treatment reduced ErbB2, ErbB3, cyclin D1, and E2F-1 transcription factor in HT-29, DLD-1, and Caco-2 colon cancer cells. These changes led to the suppression of over proliferation of cancerous cells (Ma et al., 2010). In another study, Lee et al. investigated the anti-cancer effects of the $B$. adolescentis-derived butanol extract in Caco-2, HT-29, and SW480 colorectal cell lines. The results showed that the butanol extract significantly promoted the activation of macrophages and upregulated the production of TNF- $\alpha$ and nitric oxide in tumor cells. These changes led to the induction of cytotoxic and anti-proliferative properties against colorectal cancer (Lee et al., 2008). Survivin is an anti-apoptotic agent, which has been reported to be a crucial agent in the inhibition of apoptosis and subsequent tumor growth, proliferation, metastases, and invasiveness in various types of cancer, especially in colorectal cancer (Hernandez et al., 2011). Tiptiri-Kourpeti et al. demonstrated that L. casei ATCC 393 administration $\left(10^{9} \mathrm{CFU} / \mathrm{ml}\right)$ in CT26 and HT29 colon carcinoma cells upregulated the expression of the ligand TRAIL, which was induced by TNF-mediated apoptosis. Furthermore, L. casei declined the level of survivin expression (Tiptiri-Kourpeti et al., 2016). By significantly decreasing the expression of $\mathrm{Bcl}-2$ and remarkable up-regulation in the expression grade of pro-apoptotic agents Bak and Bax, probiotic intervention with $L$. paracasei K5 showed antiproliferative effects in Caco-2 cells (Chondrou et al., 2018). In another investigation, Chen et al. reported that various strains of Lactobacillus genera in HT-29 colon cancer cells promoted the expression level of the Bax protein, while decreasing the expression of Bcl-2, leading to a notable increase in the Bax/ Bcl-2 ratio. Furthermore, the increased lactate dehydrogenase activity and the ensuing degradation of the cell membrane of tumor cells were observed (Chen et al., 2017). A summary of mechanistic in vitro investigations on probiotics and colon cancer is summarized in Table 4.

\section{Probiotics and Other Gastrointestinal Cancer}

The mitogen-activated protein kinase (MAPK) signaling pathway has crucial roles in the induction of intracellular responses from extracellular signals in cells. Aberrant regulation of this pathway leads to numerous homeostatic and pathologic sequels, such as cancer (Chapnick et al., 2011). In the KB oral cancer cell line, probiotic intervention with L. plantarum reduced the expression of MAPK and caused significant upregulation in the expression of PTEN signaling transduction (Asoudeh-Fard et al., 2017). Zhang and others evaluated the properties of Lactobacillus salivarius ( $L$. salivarius) REN supplementation in an animal model of 4nitroquinoline-1-oxide-induced oral cancer. By decreasing the expression level of COX-2 and proliferating cell nuclear antigen (PCNA), L. salivarius intervention had significant inhibitory effects on tumor growth of oral cancer (Zhang et al., 2013). Another study demonstrated that Acetobacter syzygii and L. acidophilus (PTCC 1643) probiotic strains caused significant cytotoxicity and inhibitory effects against the KB cancer cell line (Aghazadeh et al., 2017). Barrett's esophagus is a pathological condition in which the lining of the distal esophagus is damaged due to the exposure of the esophagus to stomach acid. In this situation, squamous epithelium of the esophagus is replaced by columnar epithelium (Spechler, 2013). Barrett's esophagus plays a critical role in the induction of esophageal cancer and acts as an important risk factor for development of esophageal cancer (Conteduca et al., 2012). Mozaffari Namin et al. reported that $B$. longum and L. acidophilus treatment of Barrett's esophagus cell 
TABLE 4 | Probiotics and colon cancer (in vitro).

\begin{tabular}{|c|c|c|c|c|}
\hline Cancer cell line & Probiotic agent & $\begin{array}{l}\text { Probiotic } \\
\text { concentration }\end{array}$ & Effect (s) & Ref. \\
\hline SW620 & Lactobacillus brevis SBL8803 & NA & $\begin{array}{l}\text { Via activating the Erk pathway and } \\
\text { inhibiting tumor growth }\end{array}$ & Sakatani et al. (2016b) \\
\hline SW620 & Lactobacillus delbrueckii & NA & $\begin{array}{l}\text { Through triggering the caspase 3- } \\
\text { mediated pathway and decreasing Bcl-2 } \\
\text { and caused apoptosis. Besides, MMP-9 } \\
\text { was decreased after intervention }\end{array}$ & Zhou et al. (2014) \\
\hline SW742 & Bifidobacterium & NA & Inhibited the growth of cancer cells & Otte et al. (2008) \\
\hline SW742 & Bifidobacterium and Lactobacillus & NA & $\begin{array}{l}\text { Prevented the development of colorectal } \\
\text { cancer }\end{array}$ & Bahmani et al. (2019) \\
\hline Colo320 and SW480 & $\begin{array}{l}\text { Lactobacillus acidophilus, Escherichia coli } \\
\text { Nissle 1917, and the probiotic mixture } \\
\text { VSL\#3 }\end{array}$ & $1 \times 10^{6} \mathrm{CFU} / \mathrm{ml}$ & Regulated the expression of COX-2 & Otte et al. (2008) \\
\hline $\begin{array}{l}\text { SW480 and } \\
\text { HCT-116 }\end{array}$ & Lactococcus lactis & NA & $\begin{array}{l}\text { Induced apoptosis in human colon cancer } \\
\text { cells and increased the ratio of } \mathrm{f} \mathrm{Bax/Bcl} 2\end{array}$ & Bohlul et al. (2019) \\
\hline НCT-116 & Lactobacillus fermentum & NA & $\begin{array}{l}\text { Lactobacillus cell-free supernatant } \\
\text { activated the intrinsic apoptosis pathway }\end{array}$ & Lee et al. (2019b) \\
\hline HCT-116 & $\begin{array}{l}\text { Lactobacillus plantarum } 27 \text { (NCDC 012), } \\
\text { Lactobacillus casei (NCDC 297), and } \\
\text { Lactobacillus brevis (NCDC 021) }\end{array}$ & NA & $\begin{array}{l}\text { Exerted anti-proliferative activities. } \\
\text { Inhibited activity of } \alpha \text {-glucosidase and } \\
\text { a-amylase }\end{array}$ & Mushtaq et al. (2019) \\
\hline HCT-116 & $\begin{array}{l}\text { Lactobacillus sp., Lactobacillus casei, and } \\
\text { Lactobacillus rhamnosus GG }\end{array}$ & $10^{9}-10^{11} \mathrm{CFU} / \mathrm{ml}$ & $\begin{array}{l}\text { Decreased the expression of MMP-9 and } \\
\text { increased protein levels of ZO-1 }\end{array}$ & Escamilla et al. (2012) \\
\hline НCT-116 & Pediococcus pentosaceus GS4 & $1.1 \times 10^{9} \mathrm{CFU} / \mathrm{ml}$ & $\begin{array}{l}\text { Downregulated NF-kB and p-Akt signaling } \\
\text { pathways }\end{array}$ & Dubey et al. (2016) \\
\hline $\begin{array}{l}\text { HCT-116, AGS, } \\
\text { A549, MCF-7, and } \\
\text { HepG2 }\end{array}$ & Aspergillus sp & NA & Exhibited anti-tumor properties & Choi et al. (2011) \\
\hline $\begin{array}{l}\text { HT-29, HCT-116, } \\
\text { and Caco-2 }\end{array}$ & Bifidobacterium bifidum BGN4 & NA & Inhibited the growth of cancer cell lines & You et al. (2004) \\
\hline HT-29 & $\begin{array}{l}\text { Lactobacillus casei K11, Lactobacillus casei } \\
\text { M5, Lactobacillus casei SB27, and } \\
\text { Lactobacillus casei } \times 12\end{array}$ & NA & $\begin{array}{l}\text { Cell cycle arrest induced at the G0/G1 } \\
\text { phase }\end{array}$ & Di et al. (2018) \\
\hline HT-29 & Lactobacillus kefiri (SGL 13) & $5 \times 10^{8} \mathrm{CFU} / \mathrm{ml}$ & $\begin{array}{l}\text { Increased Bax expression and decreased } \\
\text { the caspase } 3 \text {, mutant p53, and IL-8 } \\
\text { expression }\end{array}$ & Brandi et al. (2019) \\
\hline HT-29 & Enterococcus faecium YF5 & $1 \times 10^{11} \mathrm{CFU}$ & Inhibited foodborne pathogens & Tan et al. (2013) \\
\hline HT-29 & $\begin{array}{l}\text { Lactobacillus acidophilus } 145 \text { and } \\
\text { Bifidobacterium Iongum } 913\end{array}$ & $\begin{array}{l}10^{6}-10^{8} \text { and } \\
10^{5} \mathrm{CFU} / \mathrm{g}\end{array}$ & Increased oxidative-induced damage & $\begin{array}{l}\text { Oberreuther-Moschner et al. } \\
\text { (2004) }\end{array}$ \\
\hline Caco-2 and HT-29 & Lactobacillus rhamnosus MD 14 & NA & $\begin{array}{l}\text { Showed anti-genotoxic and cytotoxic } \\
\text { properties against colon cancer }\end{array}$ & Sharma et al. (2019) \\
\hline HT-29 & Lactobacillus casei 01 & $10^{9} \mathrm{CFU} / \mathrm{ml}$ & Exerted cytotoxic effects & Liu et al. (2011b) \\
\hline HT-29 & $\begin{array}{l}\text { Lactobacillus casei ATCC 393, Lactobacillus } \\
\text { plantarum ATCC 14917, and Lactobacillus } \\
\text { paracasei K5 }\end{array}$ & $10^{9} \mathrm{CFU} / \mathrm{ml}$ & $\begin{array}{l}\text { Caused a significant decrease in } \\
\text { proliferation of cancer cells in a time- and } \\
\text { dose-dependent manner }\end{array}$ & Mantzourani et al. (2019) \\
\hline HT-29 and Caco-2 & $\begin{array}{l}\text { VSL3(Lactobacillus acidophilus, } \\
\text { Lactobacillus bulgaricus, Lactobacillus } \\
\text { casei, Lactobacillus plantarum, } \\
\text { Bifidobacterium breve, Bifidobacterium } \\
\text { infantis, Bifidobacterium longum, and } \\
\text { Streptococcus thermophilus) }\end{array}$ & NA & Increased the expression of PPAR $\gamma$ & Ewaschuk et al. (2006) \\
\hline HT-29 and L-929 & $\begin{array}{l}\text { Lactobacillus paracasei and Lactobacillus } \\
\text { brevis }\end{array}$ & NA & Induced apoptosis in cancer cells & Mojibi et al. (2019) \\
\hline HT-29 & Lactobacillus acidophilus 606 & NA & $\begin{array}{l}\text { Exerted anti-tumorigenic properties by } \\
\text { inducing the expression of Beclin-1, } \\
\text { GRP78, Bcl-2, and Bak }\end{array}$ & Kim et al. (2010) \\
\hline HT-29 and HCT-116 & Lactobacillus plantarum & NA & $\begin{array}{l}\text { Increased the activity of caspase- } 3 \text { and } \\
\text { suppressed the Wnt/ } \beta \text {-catenin signaling } \\
\text { pathway. Therefore, reversed } \\
\text { chemoresistance and enhanced the } \\
\text { therapeutic effect of } 5 \text {-FU in colon cancer }\end{array}$ & Mirzaei et al. (2016) \\
\hline HT-29 and HCT-116 & Lactobacillus spp & $3 \times 10^{8} \mathrm{CFU} / \mathrm{ml}$ & $\begin{array}{l}\text { Down-regulated expression of IL-1 } \beta \text { and } \\
\text { TNF-a.cfos and cjun transcripts were } \\
\text { significantly upregulated after probiotic } \\
\text { intervention }\end{array}$ & Shyu et al. (2014) \\
\hline
\end{tabular}


TABLE 4 | (Continued) Probiotics and colon cancer (in vitro).

\begin{tabular}{|c|c|c|c|c|}
\hline Cancer cell line & Probiotic agent & $\begin{array}{l}\text { Probiotic } \\
\text { concentration }\end{array}$ & Effect (s) & Ref. \\
\hline HT-29 & $\begin{array}{l}\text { Lactobacillus paracasei subsp. } \\
\text { paracasei M5L }\end{array}$ & $10^{9} \mathrm{CFU} / \mathrm{ml}$ & $\begin{array}{l}\text { Via generating ROS production, inducing } \\
\text { cell cycle arrest, and calreticulin } \\
\text { translocation }\end{array}$ & Hu et al. (2015b) \\
\hline HT-29 & Leuconostoc mesenteroides & NA & $\begin{array}{l}\text { By regulating MAPK1, Bax, and caspase } 3 \\
\text { and downregulation of Akt, NF-Kb, and } \\
\text { Bcl-XL promoted apoptosis. Besides, } \\
\text { suppressed the expression of miRNA-21 } \\
\text { and miRNA-200b }\end{array}$ & Zununi Vahed et al. (2017) \\
\hline $\begin{array}{l}\text { HT-29, Caco2, and } \\
\text { HeLa }\end{array}$ & $\begin{array}{l}\text { Propionibacterium acidipropionici strain } \\
\text { CNRZ80, Propionibacterium freudenreichii } \\
\text { subsp. freudenreichii strain ITG18, and } \\
\text { Propionibacterium freudenreichii subsp. } \\
\text { shermanii strain SI41 }\end{array}$ & NA & $\begin{array}{l}\text { Via short-chain fatty acids acting on the } \\
\text { mitochondria, caused apoptosis in cancer } \\
\text { cells }\end{array}$ & Jan et al. (2002) \\
\hline HT-29 and HCT-116 & Propionibacterium freudenreichii & NA & $\begin{array}{l}\text { Induced apoptosis by increasing pro- } \\
\text { apoptotic gene expression (TRAIL-R2/ } \\
\text { DR5) and decreasing FLIP and XIAP. }\end{array}$ & Cousin et al. (2016) \\
\hline Caco-2 & $\begin{array}{l}\text { Bifidobacterium animalis subsp. lactis } \\
\text { DSM10140, Bifidobacterium longum subsp. } \\
\text { longum DSM20097, and Bifidobacterium } \\
\text { breve DSM20213 }\end{array}$ & $>5.0$ logs CFU/g & Caused remarkable cytotoxic activities & Ayyash et al. (2018) \\
\hline Caco-2 & $\begin{array}{l}\text { Lactobacillus rhamnosus and } \\
\text { Bifidobacterium lactis }\end{array}$ & $10^{8} \mathrm{CFU} / \mathrm{ml}$ & $\begin{array}{l}\text { Induced FAS-independent apoptosis and } \\
\text { increased BAX translocation and release of } \\
\text { cytochrome } c \text { and cleavage of caspase-3 } \\
\text { and }-9\end{array}$ & Altonsy et al. (2010) \\
\hline Caco-2 and HT-29 & $\begin{array}{l}\text { Lactobacillus plantarum A7 and } \\
\text { Lactobacillus rhamnosus GG }\end{array}$ & NA & Decreased the growth rate of cancer cells & Sadeghi-Aliabadi et al. (2014) \\
\hline Caco-2 & Escherichia coli Nissle 1917 & $25 \times 10^{7} \mathrm{CFU}$ & Decreased ROS generation & Wang et al. (2015) \\
\hline Caco-2 & Lactobacillus plantarum & NA & $\begin{array}{l}\text { Upregulated the mRNA expression of } \\
\text { HBD- } 2 \text { and modulated the TLR- } 2 \text { and IL- } \\
23 \text { expression }\end{array}$ & Paolillo et al. (2009) \\
\hline Caco-2 & Lactobacillus paracasei & $10^{8} \mathrm{CFU} / \mathrm{ml}$ & Inhibited the mRNA expressions of CXCR4 & Nozari et al. (2019) \\
\hline Caco-2 & $\begin{array}{l}\text { Pediococcus pentosaceus FP3, } \\
\text { Lactobacillus salivarius FP25, Lactobacillus } \\
\text { salivarius FP35, and Enterococcus faecium } \\
\text { FP51 }\end{array}$ & NA & $\begin{array}{l}\text { Triggered the biosynthesis of short-chain } \\
\text { fatty acids }\end{array}$ & $\begin{array}{l}\text { Thirabunyanon and } \\
\text { Hongwittayakorn, (2013) }\end{array}$ \\
\hline Caco-2 and CLS & $\begin{array}{l}\text { Enterococcus faecium RM11 and } \\
\text { Lactobacillus fermentum RM28 }\end{array}$ & NA & $\begin{array}{l}\text { Triggered anti-proliferative activities in } \\
\text { colon cancer cells }\end{array}$ & Thirabunyanon et al. (2009) \\
\hline $\begin{array}{l}\text { Caco2, SKCO-1, } \\
\text { SW620, and IEC-18 }\end{array}$ & Lactobacillus casei ATCC334 & NA & $\begin{array}{l}\text { Suppressed colon cancer progression via } \\
\text { affecting the JNK pathway }\end{array}$ & Konishi et al. (2016) \\
\hline DLD-1 & Lactobacillus rhamnosus strain GG & $10^{8} \mathrm{CFU} / \mathrm{ml}$ & Exerted anti-proliferative effects & Orlando et al. (2009) \\
\hline DLD-1 & $\begin{array}{l}\text { Lactobacillus rhamnosus (LR) KCTC } \\
\text { 12202BP }\end{array}$ & NA & $\begin{array}{l}\text { Inhibited cell proliferation through affecting } \\
\text { the p53-p21-cyclin B1/Cdk1 signaling } \\
\text { pathway }\end{array}$ & An et al. (2019) \\
\hline $\mathrm{TC}-1$ & $\begin{array}{l}\text { Lactobacillus casei BL23, Lactococcus } \\
\text { lactis MG1363, and Lactococcus lactis } \\
\text { NZ9000 }\end{array}$ & $\begin{array}{l}1 \times 10^{9} \mathrm{CFU} \text { of each } \\
\text { strain or recombinant }\end{array}$ & $\begin{array}{l}\text { Probiotic strain Lactobacillus casei BL23 } \\
\text { caused IL-2-mediated anti-tumoral } \\
\text { properties }\end{array}$ & Jacouton et al. (2018) \\
\hline CT-26 & $\begin{array}{l}\text { Lactobacillus casei variety rhamnosus } \\
\text { (Lcr35) }\end{array}$ & $\begin{array}{l}1 \times 10^{3-7} \mathrm{CFU} \text { of the } \\
\text { probiotics }\end{array}$ & $\begin{array}{l}\text { Downregulated the expression of TNF- } \alpha \\
\text { and IL-6 }\end{array}$ & Chang et al. (2018) \\
\hline CT-26 & Lactobacillus acidophilus NCFM & $1 \times 10^{8} \mathrm{CFU}$ & $\begin{array}{l}\text { Suppressed tumor growth in intestinal } \\
\text { tissue }\end{array}$ & Chen et al. (2012) \\
\hline $\begin{array}{l}\text { MCF-7, HT-29, } \\
\text { HeLa, HepG2, HL60, } \\
\text { K562, and MCF-10A }\end{array}$ & Lactobacillus plantarum strains & NA & $\begin{array}{l}\text { Caused anti-proliferative and pro- } \\
\text { apoptotic effects against malignant cancer } \\
\text { cells }\end{array}$ & Chuah et al. (2019) \\
\hline LS513 & $\begin{array}{l}\text { Lactobacillus acidophilus CL1285 and } \\
\text { Lactobacillus casei LBC80R }\end{array}$ & $10^{8} \mathrm{CFU} / \mathrm{ml}$ & $\begin{array}{l}\text { Via upregulating the caspase- } 3 \text { protein and } \\
\text { enhanced the pro-apoptotic capacity of } \\
\text { the } 5 \text {-FU. }\end{array}$ & Baldwin et al. (2010) \\
\hline
\end{tabular}

lines downregulated the expression of CDX1 (caudal type homeobox 1), COX-2, TNF- $\alpha$, and p53, while the expression level of IL-18 was enhanced after intervention of both probiotic strains (Mozaffari Namin et al., 2015). Table 5 provides a summary on the effectiveness of probiotics for oral, esophageal, and pancreatic cancer. 
TABLE 5 | Probiotics and other gastrointestinal cancers.

\begin{tabular}{|c|c|c|c|c|c|c|c|}
\hline Cancer & Probiotic agent & Probiotic concentration & $\begin{array}{l}\text { Duration } \\
\text { of the } \\
\text { study }\end{array}$ & Effect (s) & Model & $\begin{array}{l}\text { Sample } \\
\text { (n) }\end{array}$ & Ref. \\
\hline Oral cancer & Lactobacillus plantarum & NA & $\begin{array}{c}2,6 \\
\text { and } 24 \mathrm{~h}\end{array}$ & $\begin{array}{l}\text { Displayed apoptosis effects via } \\
\text { upregulating PTEN and } \\
\text { downregulating MAPK signaling } \\
\text { pathways }\end{array}$ & In vitro & NA & $\begin{array}{l}\text { Asoudeh-Fard } \\
\text { et al. (2017) }\end{array}$ \\
\hline Oral cancer & $\begin{array}{l}\text { Lactobacillus } \\
\text { salivarius REN }\end{array}$ & $5 \times 10^{10} \mathrm{CFU} / \mathrm{kg}$ per day & 32 weeks & $\begin{array}{l}\text { Inhibited rat oral cancer } \\
\text { progression through regulating the } \\
\text { expression of COX-2 and PCNA. }\end{array}$ & In vivo & NA & Zhang et al. (2013) \\
\hline Oral cancer & $\begin{array}{l}\text { Acetobacter syzygii and } \\
\text { Lactobacillus acidophilus } \\
\text { (PTCC 1643) }\end{array}$ & $\begin{array}{l}\text { Acetobacter syzygii: } 60 \mu \mathrm{g} / \\
\mathrm{ml} \text { and Lactobacillus } \\
\text { acidophilus: } 10 \mu \mathrm{g} / \mathrm{ml}\end{array}$ & $24 \mathrm{~h}$ & $\begin{array}{l}\text { Exhibited cytotoxicity against } \\
\text { cancer cell lines }\end{array}$ & In vitro & NA & $\begin{array}{l}\text { Aghazadeh et al. } \\
(2017)\end{array}$ \\
\hline $\begin{array}{l}\text { Barrett's } \\
\text { esophagus }\end{array}$ & $\begin{array}{l}\text { Bifidobacterium longum } \\
\text { and Lactobacillus } \\
\text { acidophilus }\end{array}$ & $\begin{array}{l}3 \times 10^{7} \text { bacteria or } \\
\text { microbes } / \mathrm{ml}\end{array}$ & $\begin{array}{l}1,3,5 \\
\text { and } 7 \mathrm{~h}\end{array}$ & $\begin{array}{l}\text { Increased the expression of IL-18 } \\
\text { while decreased the expression of } \\
\text { CDX1, COX-2, and TNF- } \alpha\end{array}$ & In vitro & NA & $\begin{array}{l}\text { Mozaffari Namin } \\
\text { et al. (2015) }\end{array}$ \\
\hline
\end{tabular}

PTEN, phosphatase and tensin homolog; MAPK, mitogen-activated protein kinase; COX-2, cyclooxygenase 2; PCNA, proliferating cell nuclear antigen; IL-18, interleukin 18; CDX1, caudal type homeobox 1; COX-2, cyclooxygenase 2; TNF- $\alpha$, tumor necrosis factor alpha.

\section{CONCLUSION}

Owing to their effects on different aspects of host health, probiotics have been demonstrated to be important tools in clinical medicine. Various investigations using a plethora of experimental models, including in vitro, animal models, and human clinical studies, have shown that by inducing anticarcinogenic properties, anti-mutagenic effects, producing short-chain fatty acids, activating the immune system of the hosts, inhibiting the bacteria-induced conversion of procarcinogens to carcinogens, and reducing intestinal $\mathrm{pH}$ (which results in reduced microbial activity), probiotics can assist in the prevention and treatment of gastrointestinal cancers. Nonetheless, to date, the benefits of probiotic strains as bio-therapeutic agents have not been adequately investigated against GI cancers. Moreover, the clinical efficacy

\section{REFERENCES}

Abdul Khalek, F. J., Gallicano, G. I., and Mishra, L. (2010). Colon Cancer Stem Cells. Gastrointest. Cancer Res. (Suppl. 1), S16-S23.

Agah, S., Alizadeh, A. M., Mosavi, M., Ranji, P., Khavari-Daneshvar, H., Ghasemian, F., et al. (2019). More protection of Lactobacillus Acidophilus Than Bifidobacterium Bifidum Probiotics on Azoxymethane-Induced Mouse colon Cancer. Probiotics Antimicrob. Proteins 11 (3), 857-864. doi:10.1007/s12602-018-9425-8

Agah, S., Alizadeh, A. M., Mosavi, M., Ranji, P., Khavari-Daneshvar, H., Ghasemian, F., et al. (2019). More Protection of Lactobacillus Acidophilus Than Bifidobacterium Bifidum Probiotics on Azoxymethane-Induced Mouse Colon Cancer. Probiotics Antimicrob. Proteins 11 (3), 857-864. doi:10.1007/s12602-018-9425-8

Aghazadeh, Z., Pouralibaba, F., and Yari Khosroushahi, A. (2017). The Prophylactic Effect of Acetobacter Syzygii Probiotic Species against Squamous Cell Carcinoma. J. Dent Res. Dent Clin. Dent Prospects 11 (4), 208-214. doi:10.15171/joddd.2017.037

Aisu, N., Tanimura, S., Yamashita, Y., Yamashita, K., Maki, K., Yoshida, Y., et al. (2015). Impact of Perioperative Probiotic Treatment for Surgical Site Infections in Patients with Colorectal Cancer. Exp. Ther. Med. 10 (3), 966-972. doi:10.3892/etm.2015.2640

Alfarouk, K. O., Bashir, A. H. H., Aljarbou, A. N., Ramadan, A. M., Muddathir, A. K., AlHoufie, S. T. S., et al. (2019). The Possible Role of Helicobacter pylori in Gastric Cancer and its Management. Front. Oncol. 9 (75), 75. doi:10.3389/fonc.2019.00075 of probiotics, especially on mortality, remains largely unexplored. Hence, more clinical studies with adequate follow-up durations are needed to obtain a clearer understanding on the potential utility of various strains and optimal doses for the administration of probiotics as pharmacological tools to combat GI cancers.

\section{AUTHOR CONTRIBUTIONS}

$\mathrm{HM}$ and AS involved in conception, design, statistical analysis and drafting of the manuscript. $\mathrm{AD}, \mathrm{FF}, \mathrm{ZB}, \mathrm{HF}, \mathrm{MA}-\mathrm{K}$, and MA contributed in data collection and manuscript drafting. All authors approved the final version for submission. MT, MG, ORT, and VT, critically revised the manuscript. All authors approved the new authorship changes.

Ali, M. S., Hussein, R. M., Gaber, Y., Hammam, O. A., and Kandeil, M. A. (2019). Modulation of JNK-1/ $\beta$-catenin Signaling byLactobacillus Casei, Inulin and Their Combination in 1,2-Dimethylhydrazine-Induced colon Cancer in Mice. RSC Adv. 9 (50), 29368-29383. doi:10.1039/c9ra04388h

Alipour Nosrani, E., Tamtaji, O. R., Alibolandi, Z., Sarkar, P., Ghazanfari, M., Azami Tameh, A., et al. (2021). Neuroprotective Effects of Probiotics Bacteria on Animal Model of Parkinson's Disease Induced by 6-hydroxydopamine: A Behavioral, Biochemical, and Histological Study. J. Immunoassay Immunochemistry 42 (2), 106-120. doi:10.1080/15321819.2020.1833917

Allen, J. L., Verghese, M., Shackelfor, L., Boateng, J., and Walker, L. T. (2015). Chemopreventive Potential of Soy Flour, Flaxseed Meal and a Probiotic in a Rat Model. Int. J. Cancer Res. 11 (2), 67-79. doi:10.3923/ ijcr.2015.67.79

Altonsy, M. O., Andrews, S. C., and Tuohy, K. M. (2010). Differential Induction of Apoptosis in Human Colonic Carcinoma Cells (Caco-2) by Atopobium, and Commensal, Probiotic and Enteropathogenic Bacteria: Mediation by the Mitochondrial Pathway. Int. J. Food Microbiol. 137 (2-3), 190-203. doi:10.1016/j.ijfoodmicro.2009.11.015

An, B. C., Hong, S., Park, H. J., Kim, B. K., Ahn, J. Y., Ryu, Y., et al. (2019). AntiColorectal Cancer Effects of Probiotic-Derived P8 Protein. Genes (Basel) 10 (8), 624. doi:10.3390/genes10080624

Appleyard, C. B., Cruz, M. L., Isidro, A. A., Arthur, J. C., Jobin, C., and De Simone, C. (2011). Pretreatment with the Probiotic VSL\#3 Delays Transition from 
Inflammation to Dysplasia in a Rat Model of Colitis-Associated Cancer. Am. J. Physiol. Gastrointest. Liver Physiol. 301 (6), G1004-G1013. doi:10.1152/ ajpgi.00167.2011

Arthur, J. C., Gharaibeh, R. Z., Uronis, J. M., Perez-Chanona, E., Sha, W., Tomkovich, S., et al. (2013). VSL\#3 Probiotic Modifies Mucosal Microbial Composition but Does Not Reduce Colitis-Associated Colorectal Cancer. Sci. Rep. 3, 2868. doi: $10.1038 /$ srep02868

Asemi, Z., Jazayeri, S., Najafi, M., Samimi, M., Mofid, V., Shidfar, F., et al. (2012). Effect of Daily Consumption of Probiotic Yogurt on Oxidative Stress in Pregnant Women: a Randomized Controlled Clinical Trial. Ann. Nutr. Metab. 60 (1), 62-68. doi:10.1159/000335468

Asemi, Z., Samimi, M., Tabasi, Z., Talebian, P., Azarbad, Z., Hydarzadeh, Z., et al. (2012). Effect of Daily Consumption of Probiotic Yoghurt on Lipid Profiles in Pregnant Women: a Randomized Controlled Clinical Trial. J. Matern. Fetal Neonatal. Med. 25 (9), 1552-1556. doi:10.3109/14767058.2011.640372

Asgari, B., Kermanian, F., Hedayat Yaghoobi, M., Vaezi, A., Soleimanifar, F., and Yaslianifard, S. (2020). The Anti-Helicobacter pylori Effects of Lactobacillus Acidophilus, L. Plantarum, and L. Rhamnosus in Stomach Tissue of C57BL/6 Mice. Visc. Med. 36 (2), 137-143. doi:10.1159/000500616

Asha, D., and Gayathri, D. (2012). Synergistic Impact of Lactobacillus Fermentum, Lactobacillus Plantarum and Vincristine on 1,2-Dimethylhydrazine-Induced Colorectal Carcinogenesis in Mice. Exp. Ther. Med. 3 (6), 1049-1054. doi:10.3892/etm.2012.536

Ashrafizadeh, M., Zarrabi, A., Hashemipour, M., Vosough, M., Najafi, M., Shahinozzaman, M., et al. (2020). Sensing the Scent of Death: Modulation of microRNAs by Curcumin in Gastrointestinal Cancers. Pharmacol. Res. 160, 105199. doi:10.1016/j.phrs.2020.105199

Asoudeh-Fard, A., Barzegari, A., Dehnad, A., Bastani, S., Golchin, A., and Omidi, Y. (2017). Lactobacillus Plantarum Induces Apoptosis in Oral Cancer KB Cells through Upregulation of PTEN and Downregulation of MAPK Signalling Pathways. Bioimpacts 7 (3), 193-198. doi:10.15171/bi.2017.22

Ayyash, M., Johnson, S. K., Liu, S.-Q., Al-Mheiri, A., and Abushelaibi, A. (2018). Cytotoxicity, Antihypertensive, Antidiabetic and Antioxidant Activities of Solid-State Fermented Lupin, Quinoa and Wheat by Bifidobacterium Species: In-Vitro Investigations. LWT 95, 295-302. doi:10.1016/ j.lwt.2018.04.099

Bahmani, F., Tajadadi-Ebrahimi, M., Kolahdooz, F., Mazouchi, M., Hadaegh, H., Jamal, A. S., et al. (2016). The Consumption of Synbiotic Bread Containing Lactobacillus Sporogenes and Inulin Affects Nitric Oxide and Malondialdehyde in Patients with Type 2 Diabetes Mellitus: Randomized, Double-Blind, PlaceboControlled Trial. J. Am. Coll. Nutr. 35 (6), 506-513. doi:10.1080/ 07315724.2015.1032443

Bahmani, S., Azarpira, N., and Moazamian, E. (2019). Anti-colon Cancer Activity of Bifidobacterium Metabolites on colon Cancer Cell Line SW742. Turk J. Gastroenterol. 30 (9), 835-842. doi:10.5152/tjg.2019.18451

Baldwin, C., Millette, M., Oth, D., Ruiz, M. T., Luquet, F. M., and Lacroix, M. (2010). Probiotic Lactobacillus Acidophilus and L. Casei Mix Sensitize Colorectal Tumoral Cells to 5-Fluorouracil-Induced Apoptosis. Nutr. Cancer 62 (3), 371-378. doi:10.1080/01635580903407197

Banys-Paluchowski, M., Fehm, T., Janni, W., Aktas, B., Fasching, P. A., KasimirBauer, S., et al. (2018). Elevated Serum RAS P21 Is an Independent Prognostic Factor in Metastatic Breast Cancer. BMC cancer 18 (1), 541. doi:10.1186/ s12885-018-4282-0

Bassaganya-Riera, J., Viladomiu, M., Pedragosa, M., De Simone, C., and Hontecillas, R. (2012). Immunoregulatory Mechanisms Underlying Prevention of Colitis-Associated Colorectal Cancer by Probiotic Bacteria. PLoS One 7 (4), e34676. doi:10.1371/journal.pone.0034676

Beamish, J. A., Juliar, B. A., Cleveland, D. S., Busch, M. E., Nimmagadda, L., and Putnam, A. J. (2019). Deciphering the Relative Roles of Matrix Metalloproteinase- and Plasmin-Mediated Matrix Degradation during Capillary Morphogenesis Using Engineered Hydrogels. J. Biomed. Mater. Res. B Appl. Biomater. 107 (8), 2507-2516. doi:10.1002/jbm.b.34341

Bernstein, H., Bernstein, C., Payne, C. M., Dvorakova, K., and Garewal, H. (2005). Bile Acids as Carcinogens in Human Gastrointestinal Cancers. Mutat. Res. 589 (1), 47-65. doi:10.1016/j.mrrev.2004.08.001

Biasco, G., Paganelli, G. M., Brandi, G., Brillanti, S., Lami, F., Callegari, C., et al. (1991). Effect of Lactobacillus Acidophilus and Bifidobacterium Bifidum on Rectal Cell Kinetics and Fecal pH. Ital. J. Gastroenterol. 23 (3), 142.
Bohlul, E., Hasanlou, F., Taromchi, A. H., and Nadri, S. (2019). TRAIL-expressing Recombinant Lactococcus Lactis Induces Apoptosis in Human colon Adenocarcinoma SW480 and HCT116 Cells. J. Appl. Microbiol. 126 (5), 1558-1567. doi:10.1111/jam.14237

Brandi, J., Di Carlo, C., Manfredi, M., Federici, F., Bazaj, A., Rizzi, E., et al. (2019). Investigating the Proteomic Profile of HT-29 Colon Cancer Cells after Lactobacillus Kefiri SGL 13 Exposure Using the SWATH Method. J. Am. Soc. Mass. Spectrom. 30 (9), 1690-1699. doi:10.1007/s13361-019-02268-6

Butt, J., and Epplein, M. (2019). Helicobacter pylori and Colorectal Cancer-A Bacterium Going Abroad? Plos Pathog. 15 (8), e1007861-e. doi:10.1371/ journal.ppat.1007861

Cahill, D. P., Kinzler, K. W., Vogelstein, B., and Lengauer, C. (1999). Genetic Instability and Darwinian Selection in Tumours. Trends Cel Biol 9 (12), M57-M60. doi:10.1016/s0962-8924(99)01661-x

Chang, C. W., Liu, C. Y., Lee, H. C., Huang, Y. H., Li, L. H., Chiau, J. C., et al. (2018). Lactobacillus Casei Variety Rhamnosus Probiotic Preventively Attenuates 5-Fluorouracil/Oxaliplatin-Induced Intestinal Injury in a Syngeneic Colorectal Cancer Model. Front. Microbiol. 9, 983. doi:10.3389/ fmicb.2018.00983

Chapnick, D. A., Warner, L., Bernet, J., Rao, T., and Liu, X. (2011). Partners in Crime: the TGF $\beta$ and MAPK Pathways in Cancer Progression. Cell Biosci 1 (1), 42-48. doi:10.1186/2045-3701-1-42

Chen, C. C., Lin, W. C., Kong, M. S., Shi, H. N., Walker, W. A., Lin, C. Y., et al. (2012). Oral Inoculation of Probiotics Lactobacillus Acidophilus NCFM Suppresses Tumour Growth Both in Segmental Orthotopic colon Cancer and Extra-intestinal Tissue. Br. J. Nutr. 107 (11), 1623-1634. doi:10.1017/ S0007114511004934

Chen, X., Fruehauf, J., Goldsmith, J. D., Xu, H., Katchar, K. K., Koon, H. W., et al. (2009). Saccharomyces Boulardii Inhibits EGF Receptor Signaling and Intestinal Tumor Growth in $\mathrm{Apc}(\mathrm{min})$ Mice. Gastroenterology 137 (3), 914-923. doi:10.1053/j.gastro.2009.05.050

Chen, Z. Y., Hsieh, Y. M., Huang, C. C., and Tsai, C. C. (2017). Inhibitory Effects of Probiotic Lactobacillus on the Growth of Human Colonic Carcinoma Cell Line HT-29. Molecules 22 (1), 107. doi:10.3390/molecules22010107

Cheng, H., Zhao, L., Ju, Z., Wang, F., Qin, M., Mao, H., et al. (2020). Effects of 10.6$\mu \mathrm{m}$ Laser Moxibustion and Electroacupuncture at ST36 in a 5-Fu-Induced Diarrhea Rat Model. Support Care Cancer, 1-9. doi:10.1007/s00520-02005788-0

Choi, E. J., Park, J. S., Kim, Y. J., Jung, J. H., Lee, J. K., Kwon, H. C., et al. (2011). Apoptosis-inducing Effect of Diketopiperazine Disulfides Produced by Aspergillus Sp. KMD 901 Isolated from marine Sediment on HCT116 colon Cancer Cell Lines. J. Appl. Microbiol. 110 (1), 304-313. doi:10.1111/j.13652672.2010.04885.x

Chondrou, P., Karapetsas, A., Kiousi, D. E., Tsela, D., Tiptiri-Kourpeti, A., Anestopoulos, I., et al. (2018). Lactobacillus Paracasei K5 Displays Adhesion, Anti-proliferative Activity and Apoptotic Effects in Human colon Cancer Cells. Benef Microbes 9 (6), 975-983. doi:10.3920/BM2017.0183

Chuah, L. O., Foo, H. L., Loh, T. C., Mohammed Alitheen, N. B., Yeap, S. K., Abdul Mutalib, N. E., et al. (2019). Postbiotic Metabolites Produced by Lactobacillus Plantarum Strains Exert Selective Cytotoxicity Effects on Cancer Cells. BMC Complement. Altern. Med. 19 (1), 114. doi:10.1186/s12906-019-2528-2

Chung, E. J., Do, E. J., Kim, S. Y., Cho, E. A., Kim, D. H., Pak, S., et al. (2017). Combination of Metformin and VSL\#3 Additively Suppresses Western-Style Diet Induced colon Cancer in Mice. Eur. J. Pharmacol. 794, 1-7. doi:10.1016/ j.ejphar.2016.11.012

Chung, I. C., OuYang, C. N., Yuan, S. N., Lin, H. C., Huang, K. Y., Wu, P. S., et al. (2019). Pretreatment with a Heat-Killed Probiotic Modulates the NLRP3 Inflammasome and Attenuates Colitis-Associated Colorectal Cancer in Mice. Nutrients 11 (3), 516. doi:10.3390/nu11030516

Chung, I. C., OuYang, C. N., Yuan, S. N., Lin, H. C., Huang, K. Y., Wu, P. S., et al. (2019). Pretreatment with a Heat-Killed Probiotic Modulates the NLRP3 Inflammasome and Attenuates Colitis-Associated Colorectal Cancer in Mice. Nutrients 11 (3). doi:10.3390/nu11030516

Čokášová, D., Bomba, A., Strojný, L., Pramuková, B., Szabadosová, V., Salaj, R., et al. (2012). The Effect of New Probiotic Strain Lactobacillus Plantarum on Counts of Coliforms, Lactobacilli and Bacterial Enzyme Activities in Rats Exposed to N, N-Dimethylhydrazine (Chemical Carcinogen). Acta Veterinaria Brno 81 (2), 189-194. 
Conteduca, V., Sansonno, D., Ingravallo, G., Marangi, S., Russi, S., Lauletta, G., et al. (2012). Barrett's Esophagus and Esophageal Cancer: an Overview. Int. J. Oncol. 41 (2), 414-424. doi:10.3892/ijo.2012.1481

Cotter, P. D., Hill, C., and Ross, R. P. (2005). Bacteriocins: Developing Innate Immunity for Food. Nat. Rev. Microbiol. 3 (10), 777-788. doi:10.1038/ nrmicrol273

Cousin, F. J., Jouan-Lanhouet, S., Dimanche-Boitrel, M. T., Corcos, L., and Jan, G. (2012). Milk Fermented by Propionibacterium Freudenreichii Induces Apoptosis of HGT-1 Human Gastric Cancer Cells. PLoS One 7 (3), e31892. doi:10.1371/journal.pone.0031892

Cousin, F. J., Jouan-Lanhouet, S., Théret, N., Brenner, C., Jouan, E., Le MoigneMuller, G., et al. (2016). The Probiotic Propionibacterium Freudenreichii as a New Adjuvant for TRAIL-Based Therapy in Colorectal Cancer. Oncotarget 7 (6), 7161-7178. doi:10.18632/oncotarget.6881

Davoodvandi, A., Marzban, H., Goleij, P., Sahebkar, A., Morshedi, K., Rezaei, S., et al. (2021). Effects of Therapeutic Probiotics on Modulation of microRNAs. Cell Commun Signal 19 (1), 4. doi:10.1186/s12964-020-00668-w

de Moreno de LeBlanc, A., and Perdigón, G. (2005). Reduction of BetaGlucuronidase and Nitroreductase Activity by Yoghurt in a Murine colon Cancer Model. Biocell 29 (1), 15-24.

De Preter, V., Hamer, H. M., Windey, K., and Verbeke, K. (2011). The Impact of Pre- And/or Probiotics on Human Colonic Metabolism: Does it Affect Human Health? Mol. Nutr. Food Res. 55 (1), 46-57. doi:10.1002/mnfr.201000451

Del Carmen, S., de Moreno de LeBlanc, A., and LeBlanc, J. G. (2016). Development of a Potential Probiotic Yoghurt Using Selected Anti-inflammatory Lactic Acid Bacteria for Prevention of Colitis and Carcinogenesis in Mice. J. Appl. Microbiol. 121 (3), 821-830. doi:10.1111/jam.13213

Del Carmen, S., de Moreno de LeBlanc, A., Levit, R., Azevedo, V., Langella, P., Bermúdez-Humarán, L. G., et al. (2017). Anti-cancer Effect of Lactic Acid Bacteria Expressing Antioxidant Enzymes or IL-10 in a Colorectal Cancer Mouse Model. Int. Immunopharmacol 42, 122-129. doi:10.1016/ j.intimp.2016.11.017

Deol, P. K., Khare, P., Bishnoi, M., Kondepudi, K. K., and Kaur, I. P. (2018). Coadministration of Ginger Extract-Lactobacillus Acidophilus (Cobiotic) Reduces Gut Inflammation and Oxidative Stress via Downregulation of COX-2, I-NOS, and C-Myc. Phytother Res. 32 (10), 1950-1956. doi:10.1002/ ptr.6121

Desrouillères, K., Millette, M., Vu, K. D., Touja, R., and Lacroix, M. (2015). Cancer Preventive Effects of a Specific Probiotic Fermented Milk Containing Lactobacillus Acidophilus CL1285, L. Casei LBC80R and L. Rhamnosus CLR2 on Male F344 Rats Treated with 1, 2-dimethylhydrazine. J. Funct. Foods 17, 816-827.

Di Cristofano, A., Pesce, B., Cordon-Cardo, C., and Pandolfi, P. P. (1998). Pten Is Essential for Embryonic Development and Tumour Suppression. Nat. Genet. 19 (4), 348-355. doi:10.1038/1235

Di, W., Zhang, L., Yi, H., Han, X., Zhang, Y., and Xin, L. (2018). Exopolysaccharides Produced by Lactobacillus Strains Suppress HT-29 Cell Growth via Induction of G0/G1 Cell Cycle Arrest and Apoptosis. Oncol. Lett. 16 (3), 3577-3586. doi:10.3892/ol.2018.9129

Do, E. J., Hwang, S. W., Kim, S. Y., Ryu, Y. M., Cho, E. A., Chung, E. J., et al. (2016). Suppression of Colitis-Associated Carcinogenesis through Modulation of IL-6/ STAT3 Pathway by Balsalazide and VSL\#3. J. Gastroenterol. Hepatol. 31 (8), 1453-1461. doi:10.1111/jgh.13280

Dubey, V., Ghosh, A. R., Bishayee, K., and Khuda-Bukhsh, A. R. (2016). Appraisal of the Anti-cancer Potential of Probiotic Pediococcus Pentosaceus GS4 against colon Cancer: In Vitro and In Vivo Approaches. J. Funct. Foods 23, 66-79. doi:10.1016/j.jff.2016.02.032

Escamilla, J., Lane, M. A., and Maitin, V. (2012). Cell-free Supernatants from Probiotic Lactobacillus Casei and Lactobacillus Rhamnosus GG Decrease colon Cancer Cell Invasion In Vitro. Nutr. Cancer 64 (6), 871-878. doi:10.1080/ 01635581.2012.700758

Eslami, M., Yousefi, B., Kokhaei, P., Hemati, M., Nejad, Z. R., Arabkari, V., et al. (2019). Importance of Probiotics in the Prevention and Treatment of Colorectal Cancer. J. Cel Physiol 234 (10), 17127-17143. doi:10.1002/jcp.28473

Ewaschuk, J. B., Walker, J. W., Diaz, H., and Madsen, K. L. (2006). Bioproduction of Conjugated Linoleic Acid by Probiotic Bacteria Occurs In Vitro and In Vivo in Mice. J. Nutr. 136 (6), 1483-1487. doi:10.1093/jn/136.6.1483
Falzone, L., Salomone, S., and Libra, M. (2018). Evolution of Cancer Pharmacological Treatments at the Turn of the Third Millennium. Front. Pharmacol. 9, 1300. doi:10.3389/fphar.2018.01300

Farajzadeh, D., Karimi-Gharigh, S., and Dastmalchi, S. (2017). Tumor Necrosis Factor-Alpha and its Inhibition Strategies. Tehran Univ. Med. J. 75 (3), 159-171.

Floch, M. H., Walker, W. A., Madsen, K., Sanders, M. E., Macfarlane, G. T., Flint, H. J., et al. (2011). Recommendations for Probiotic Use-2011 Update. J. Clin. Gastroenterol. 45, S168-S171. doi:10.1097/MCG.0b013e318230928b

Fu, J., Xu, Y., Yang, Y., Liu, Y., Ma, L., and Zhang, Y. (2019). Aspirin Suppresses Chemoresistance and Enhances Antitumor Activity of 5-Fu in 5-Fu-Resistant Colorectal Cancer by Abolishing 5-Fu-Induced NF-Kb Activation. Sci. Rep. 9 (1), 16937. doi:10.1038/s41598-019-53276-1

Gamallat, Y., Meyiah, A., Kuugbee, E. D., Hago, A. M., Chiwala, G., Awadasseid, A., et al. (2016). Lactobacillus Rhamnosus Induced Epithelial Cell Apoptosis, Ameliorates Inflammation and Prevents colon Cancer Development in an Animal Model. Biomed. Pharmacother. 83, 536-541. doi:10.1016/ j.biopha.2016.07.001

Ganguly, N., Bhattacharya, S., Sesikeran, B., Nair, G., Ramakrishna, B., Sachdev, H., et al. (2011). ICMR-DBT Guidelines for Evaluation of Probiotics in Food. Indian J. Med. Res. 134 (1), 22-25.

Gao, Z., Guo, B., Gao, R., Zhu, Q., Wu, W., and Qin, H. (2015). Probiotics Modify Human Intestinal Mucosa-Associated Microbiota in Patients with Colorectal Cancer. Mol. Med. Rep. 12 (4), 6119-6127. doi:10.3892/mmr.2015.4124

Garrett, W. S. (2015). Cancer and the Microbiota. Science 348 (6230), 80-86. doi:10.1126/science.aaa4972

Gianotti, L., Morelli, L., Galbiati, F., Rocchetti, S., Coppola, S., Beneduce, A., et al. (2010). A Randomized Double-Blind Trial on Perioperative Administration of Probiotics in Colorectal Cancer Patients. World J. Gastroenterol. 16 (2), 167-175. doi:10.3748/wjg.v16.i2.167

Górska, A., Przystupski, D., Niemczura, M. J., and Kulbacka, J. (2019). Probiotic Bacteria: A Promising Tool in Cancer Prevention and Therapy. Curr. Microbiol. 76 (8), 939-949. doi:10.1007/s00284-019-01679-8

Hatakka, K., Mutanen, M., Holma, R., Saxelin, M., and Korpela, R. (2008). Lactobacillus Rhamnosus LC705 Together with Propionibacterium Freudenreichii Ssp Shermanii JS Administered in Capsules Is Ineffective in Lowering Serum Lipids. J. Am. Coll. Nutr. 27 (4), 441-447. doi:10.1080/ 07315724.2008.10719723

Hayatsu, H., and Hayatsu, T. (1993). Suppressing Effect of Lactobacillus Casei Administration on the Urinary Mutagenicity Arising from Ingestion of Fried Ground Beef in the Human. Cancer Lett. 73 (2-3), 173-179. doi:10.1016/03043835(93)90261-7

Hernandez, J. M., Farma, J. M., Coppola, D., Hakam, A., Fulp, W. J., Chen, D. T., et al. (2011). Expression of the Antiapoptotic Protein Survivin in colon Cancer. Clin. Colorectal Cancer 10 (3), 188-193. doi:10.1016/j.clcc.2011.03.014

Hruban, R. H., Adsay, N. V., Albores-Saavedra, J., Compton, C., Garrett, E. S., Goodman, S. N., et al. (2001). Pancreatic Intraepithelial Neoplasia: a New Nomenclature and Classification System for Pancreatic Duct Lesions. Am. J. Surg. Pathol. 25 (5), 579-586. doi:10.1097/00000478-200105000-00003

Hruban, R. H., Takaori, K., Klimstra, D. S., Adsay, N. V., Albores-Saavedra, J., Biankin, A. V., et al. (2004). An Illustrated Consensus on the Classification of Pancreatic Intraepithelial Neoplasia and Intraductal Papillary Mucinous Neoplasms. Am. J. Surg. Pathol. 28 (8), 977-987. doi:10.1097/ 01.pas.0000126675.59108.80

Hu, D., Bi, X., Fang, W., Han, A., and Yang, W. (2009). GSK3beta Is Involved in JNK2-Mediated Beta-Catenin Inhibition. PLoS One 4 (8), e6640. doi:10.1371/ journal.pone. 0006640

Hu, J., Wang, C., Ye, L., Yang, W., Huang, H., Meng, F., et al. (2015). Anti-tumour Immune Effect of Oral Administration of Lactobacillus Plantarum to CT26 Tumour-Bearing Mice. J. Biosci. 40 (2), 269-279. doi:10.1007/s12038015-9518-4

Hu, P., Song, W., Shan, Y., Du, M., Huang, M., Song, C., et al. (2015). Lactobacillus Paracasei Subsp. Paracasei M5L Induces Cell Cycle Arrest and Calreticulin Translocation via the Generation of Reactive Oxygen Species in HT-29 Cell Apoptosis. Food Funct. 6 (7), 2257-2265. doi:10.1039/c5fo00248f

Huang, L., Shan, Y.-J., He, C.-X., Ren, M.-H., Tian, P.-J., and Song, W. (2016). Effects of L. Paracasei Subp. Paracasei X12 on Cell Cycle of colon Cancer HT-29 
Cells and Regulation of mTOR Signalling Pathway. J. Funct. Foods 21, 431-439. doi:10.1016/j.jff.2015.12.024

Irecta-Nájera, C. A., del Rosario Huizar-López, M., Casas-Solís, J., Castro-Félix, P., and Santerre, A. (2017). Protective Effect of Lactobacillus Casei on DMHInduced colon Carcinogenesis in Mice. Probiotics Antimicrob. Proteins 9 (2), 163-171.

Irecta-Nájera, C. A., Del Rosario Huizar-López, M., Casas-Solís, J., Castro-Félix, P., and Santerre, A. (2017). Protective Effect of Lactobacillus Casei on DMHInduced Colon Carcinogenesis in Mice. Probiotics Antimicrob. Proteins 9 (2), 163-171. doi:10.1007/s12602-017-9253-2

Ishikawa, H., Akedo, I., Otani, T., Suzuki, T., Nakamura, T., Takeyama, I., et al. (2005). Randomized Trial of Dietary Fiber and Lactobacillus Casei Administration for Prevention of Colorectal Tumors. Int. J. Cancer 116 (5), 762-767. doi:10.1002/ijc.21115

Jacouton, E., Chain, F., Sokol, H., Langella, P., and Bermúdez-Humarán, L. G. (2017). Probiotic Strain Lactobacillus Casei BL23 Prevents Colitis-Associated Colorectal Cancer. Front. Immunol. 8, 1553. doi:10.3389/fimmu.2017.01553

Jacouton, E., Michel, M. L., Torres-Maravilla, E., Chain, F., Langella, P., and Bermúdez-Humarán, L. G. (2018). Elucidating the Immune-Related Mechanisms by Which Probiotic Strain Lactobacillus Casei BL23 Displays Anti-tumoral Properties. Front. Microbiol. 9, 3281. doi:10.3389/ fmicb.2018.03281

Jan, G., Belzacq, A. S., Haouzi, D., Rouault, A., Métivier, D., Kroemer, G., et al. (2002). Propionibacteria Induce Apoptosis of Colorectal Carcinoma Cells via Short-Chain Fatty Acids Acting on Mitochondria. Cell Death Differ 9 (2), 179-188. doi:10.1038/sj.cdd.4400935

Javanmard, A., Ashtari, S., Sabet, B., Davoodi, S. H., Rostami-Nejad, M., Esmaeil Akbari, M., et al. (2018). Probiotics and Their Role in Gastrointestinal Cancers Prevention and Treatment; an Overview. Gastroenterol. Hepatol. Bed Bench 11 (4), 284-295.

Jeong, J. K., Chang, H. K., and Park, K. Y. (2012). Inhibitory Effects of Meju Prepared with Mixed Starter Cultures on Azoxymethane and Dextran Sulfate Sodium-Induced colon Carcinogenesis in Mice. J. Carcinog 11, 13. doi:10.4103/ 1477-3163.100404

Jia, W., Xie, G., and Jia, W. (2018). Bile Acid-Microbiota Crosstalk in Gastrointestinal Inflammation and Carcinogenesis. Nat. Rev. Gastroenterol. Hepatol. 15 (2), 111-128. doi:10.1038/nrgastro.2017.119

Kahouli, I., Malhotra, M., Westfall, S., Alaoui-Jamali, M. A., and Prakash, S. (2017). Design and Validation of an Orally Administrated Active L. Fermentum-L. Acidophilus Probiotic Formulation Using Colorectal Cancer Apc Min/+ Mouse Model. Appl. Microbiol. Biotechnol. 101 (5), 1999-2019. doi:10.1007/s00253016-7885-x

Khazaie, K., Zadeh, M., Khan, M. W., Bere, P., Gounari, F., Dennis, K., et al. (2012). Abating colon Cancer Polyposis by Lactobacillus Acidophilus Deficient in Lipoteichoic Acid. Proc. Natl. Acad. Sci. U S A. 109 (26), 10462-10467. doi:10.1073/pnas.1207230109

Khoder, G., Al-Menhali, A. A., Al-Yassir, F., and Karam, S. M. (2016). Potential Role of Probiotics in the Management of Gastric Ulcer. Exp. Ther. Med. 12 (1), 3-17. doi:10.3892/etm.2016.3293

Kim, E. C., and Lance, P. (1997). Colorectal Polyps and Their Relationship to Cancer. Gastroenterol. Clin. North. Am. 26 (1), 1-17. doi:10.1016/s08898553(05)70280-6

Kim, Y., Lee, D., Kim, D., Cho, J., Yang, J., Chung, M., et al. (2008). Inhibition of Proliferation in colon Cancer Cell Lines and Harmful Enzyme Activity of colon Bacteria by Bifidobacterium Adolescentis SPM0212. Arch. Pharm. Res. 31 (4), 468-473. doi:10.1007/s12272-001-1180-y

Kim, Y., Oh, S., Yun, H. S., Oh, S., and Kim, S. H. (2010). Cell-bound Exopolysaccharide from Probiotic Bacteria Induces Autophagic Cell Death of Tumour Cells. Lett. Appl. Microbiol. 51 (2), 123-130. doi:10.1111/j.1472765X.2010.02859.x

Konishi, H., Fujiya, M., Tanaka, H., Ueno, N., Moriichi, K., Sasajima, J., et al. (2016). Probiotic-derived Ferrichrome Inhibits colon Cancer Progression via JNK-Mediated Apoptosis. Nat. Commun. 7, 12365. doi:10.1038/ncomms12365 Kotzampassi, K., Stavrou, G., Damoraki, G., Georgitsi, M., Basdanis, G., Tsaousi, G., et al. (2015). A Four-Probiotics Regimen Reduces Postoperative Complications after Colorectal Surgery: a Randomized, Double-Blind, Placebo-Controlled Study. World J. Surg. 39 (11), 2776-2783. doi:10.1007/ s00268-015-3071-z
Kumar, M., Kumar, A., Nagpal, R., Mohania, D., Behare, P., Verma, V., et al. (2010). Cancer-preventing Attributes of Probiotics: an Update. Int. J. Food Sci. Nutr. 61 (5), 473-496. doi:10.3109/09637480903455971

Kumar, R. S., Kanmani, P., Yuvaraj, N., Paari, K. A., Pattukumar, V., Thirunavukkarasu, C., et al. (2012). Lactobacillus Plantarum AS1 Isolated from South Indian Fermented Food Kallappam Suppress 1,2-dimethyl Hydrazine (DMH)-induced Colorectal Cancer in Male Wistar Rats. Appl. Biochem. Biotechnol. 166 (3), 620-631. doi:10.1007/s12010-011-9453-2

Lalla, R. V., Bowen, J., Barasch, A., Elting, L., Epstein, J., Keefe, D. M., et al. (2014). MASCC/ISOO Clinical Practice Guidelines for the Management of Mucositis Secondary to Cancer Therapy. Cancer 120 (10), 1453-1461. doi:10.1002/ cncr.28592

Lan, A., Bruneau, A., Bensaada, M., Philippe, C., Bellaud, P., Rabot, S., et al. (2008). Increased Induction of Apoptosis by Propionibacterium Freudenreichii TL133 in Colonic Mucosal Crypts of Human Microbiota-Associated Rats Treated with 1,2-dimethylhydrazine. Br. J. Nutr. 100 (6), 1251-1259. doi:10.1017/ S0007114508978284

Lee, D. K., Jang, S., Kim, M. J., Kim, J. H., Chung, M. J., Kim, K. J., et al. (2008). Anti-proliferative Effects of Bifidobacterium Adolescentis SPM0212 Extract on Human colon Cancer Cell Lines. BMC cancer 8 (1), 310. doi:10.1186/14712407-8-310

Lee, J. E., Lee, J., Kim, J. H., Cho, N., Lee, S. H., Park, S. B., et al. (2019). Characterization of the Anti-cancer Activity of the Probiotic Bacterium Lactobacillus Fermentum Using 2D vs. 3D Culture in Colorectal Cancer Cells. Biomolecules 9 (10), 557. doi:10.3390/biom9100557

Lee, J. Y., Chu, S. H., Jeon, J. Y., Lee, M. K., Park, J. H., Lee, D. C., et al. (2014). Effects of 12 Weeks of Probiotic Supplementation on Quality of Life in Colorectal Cancer Survivors: a Double-Blind, Randomized, PlaceboControlled Trial. Dig. Liver Dis. 46 (12), 1126-1132. doi:10.1016/ j.dld.2014.09.004

Lee, Y. R., Chen, M., Lee, J. D., Zhang, J., Lin, S. Y., Fu, T. M., et al. (2019). Reactivation of PTEN Tumor Suppressor for Cancer Treatment through Inhibition of a MYC-WWP1 Inhibitory Pathway. Science 364 (6441). doi:10.1126/science.aau0159

Lenoir, M., Del Carmen, S., Cortes-Perez, N. G., Lozano-Ojalvo, D., MuñozProvencio, D., Chain, F., et al. (2016). Lactobacillus Casei BL23 Regulates Treg and Th17 T-Cell Populations and Reduces DMH-Associated Colorectal Cancer. J. Gastroenterol. 51 (9), 862-873. doi:10.1007/ s00535-015-1158-9

Li, L., and Neaves, W. B. (2006). Normal Stem Cells and Cancer Stem Cells: the Niche Matters. Cancer Res. 66 (9), 4553-4557. doi:10.1158/0008-5472.CAN-053986

Liang, S., Xu, L., Zhang, D., and Wu, Z. (2016). Effect of Probiotics on Small Intestinal Bacterial Overgrowth in Patients with Gastric and Colorectal Cancer. Turk J. Gastroenterol. 27 (3), 227-232. doi:10.5152/tjg.2016.15375

Lidbeck, A., Övervik, E., Rafter, J., Nord, C. E., and Gustafsson, J.-A. (1992). Effect of Lactobacillus Acidophilus Supplements on Mutagen Excretion in Faeces and Urine in Humans. Microb. Ecol. Health Dis. 5 (1), 59-67. doi:10.3109/ 08910609209141305

Lin, C. C., Huang, W. C., Su, C. H., Lin, W. D., Wu, W. T., Yu, B., et al. (2020). Effects of Multi-Strain Probiotics on Immune Responses and Metabolic Balance in Helicobacter Pylori-Infected Mice. Nutrients 12 (8), 2476. doi:10.3390/ nu12082476

Lin, J., and Beerm, D. G. (2004). Molecular Biology of Upper Gastrointestinal Malignancies. Semin. Oncol. 31 (4), 476-486. doi:10.1053/ j.seminoncol.2004.04.019

Lin, P. Y., Li, S. C., Lin, H. P., and Shih, C. K. (2019). Germinated Brown rice Combined with Lactobacillus Acidophilus and Bifidobacterium Animalis Subsp. Lactis Inhibits Colorectal Carcinogenesis in Rats. Food Sci. Nutr. 7 (1), 216-224. doi:10.1002/fsn3.864

Linsalata, M., Cavallini, A., Messa, C., Orlando, A., Refolo, M. G., and Russo, F. (2010). Lactobacillus Rhamnosus GG Influences Polyamine Metabolism in HGC-27 Gastric Cancer Cell Line: a Strategy toward Nutritional Approach to Chemoprevention of Gastric Cance. Curr. Pharm. Des. 16 (7), 847-853. doi:10.2174/138161210790883598

Liong, M. T. (2008). Roles of Probiotics and Prebiotics in colon Cancer Prevention: Postulated Mechanisms and In-Vivo Evidence. Int. J. Mol. Sci. 9 (5), 854-863. doi:10.3390/ijms 9050854 
Liu, C. T., Chu, F. J., Chou, C. C., and Yu, R. C. (2011). Antiproliferative and Anticytotoxic Effects of Cell Fractions and Exopolysaccharides from Lactobacillus Casei 01. Mutat. Res. 721 (2), 157-162. doi:10.1016/ j.mrgentox.2011.01.005

Liu, Z., Qin, H., Yang, Z., Xia, Y., Liu, W., Yang, J., et al. (2011). Randomised Clinical Trial: the Effects of Perioperative Probiotic Treatment on Barrier Function and post-operative Infectious Complications in Colorectal Cancer Surgery - a Double-Blind Study. Aliment. Pharmacol. Ther. 33 (1), 50-63. doi:10.1111/j.1365-2036.2010.04492.x

Liu, Z. H., Huang, M. J., Zhang, X. W., Wang, L., Huang, N. Q., Peng, H., et al. (2012). The Effects of Perioperative Probiotic Treatment on Serum Zonulin Concentration and Subsequent Postoperative Infectious Complications after Colorectal Cancer Surgery: a Double-center and Double-Blind Randomized Clinical Trial. Am. J. Clin. Nutr. 97 (1), 117-126. doi:10.3945/ajen.112.040949

Lynch, J. P., and Hoops, T. C. (2002). The Genetic Pathogenesis of Colorectal Cancer. Hematol. Oncol. Clin. North. Am. 16 (4), 775-810. doi:10.1016/s08898588(02)00029-1

Ma, E. L., Choi, Y. J., Choi, J., Pothoulakis, C., Rhee, S. H., and Im, E. (2010). The Anticancer Effect of Probiotic Bacillus Polyfermenticus on Human colon Cancer Cells Is Mediated through ErbB2 and ErbB3 Inhibition. Int. J. Cancer 127 (4), 780-790. doi:10.1002/ijc.25011

Ma, Q., Wang, Y., Gao, X., Ma, Z., and Song, Z. (2007). L-arginine Reduces Cell Proliferation and Ornithine Decarboxylase Activity in Patients with Colorectal Adenoma and Adenocarcinoma. Clin. Cancer Res. 13 (24), 7407-7412. doi:10.1158/1078-0432.CCR-07-0751

Madempudi, R. S., and Kalle, A. M. (2017). Antiproliferative Effects of Bacillus Coagulans Unique IS2 in colon Cancer Cells. Nutr. Cancer 69 (7), 1062-1068. doi:10.1080/01635581.2017.1359317

Mahkonen, A., Putaala, H., Mustonen, H., Rautonen, N., and Puolakkainen, P. (2008). Lactobacillus Acidophilus 74-2 and Butyrate Induce Cyclooxygenase (COX)-1 Expression in Gastric Cancer Cells. Immunopharmacol Immunotoxicol 30 (3), 503-518. doi:10.1080/08923970802135229

Mahmood, N., Mihalcioiu, C., and Rabbani, S. A. (2018). Multifaceted Role of the Urokinase-type Plasminogen Activator (uPA) and its Receptor (uPAR): Diagnostic, Prognostic, and Therapeutic Applications. Front. Oncol. 8, 24. doi:10.3389/fonc.2018.00024

Maleki-Kakelar, H., Dehghani, J., Barzegari, A., Barar, J., Shirmohamadi, M., Sadeghi, J., et al. (2020). Lactobacillus Plantarum Induces Apoptosis in Gastric Cancer Cells via Modulation of Signaling Pathways in Helicobacter pylori. Bioimpacts 10 (2), 65-72. doi:10.34172/bi.2020.09

Mantzourani, I., Chondrou, P., Bontsidis, C., Karolidou, K., Terpou, A., Alexopoulos, A., et al. (2019). Assessment of the Probiotic Potential of Lactic Acid Bacteria Isolated from Kefir Grains: Evaluation of Adhesion and Antiproliferative Properties in In Vitro Experimental Systems. Ann. Microbiol. 69 (7), 751-763. doi:10.1007/s13213-019-01467-6

McIntosh, G. H., Royle, P. J., and Playne, M. J. (1999). A Probiotic Strain of L. Acidophilus Reduces DMH-Induced Large Intestinal Tumors in Male SpragueDawley Rats. Nutr. Cancer 35 (2), 153-159. doi:10.1207/S15327914NC352_9

Mego, M., Holec, V., Drgona, L., Hainova, K., Ciernikova, S., and Zajac, V. (2013). Probiotic Bacteria in Cancer Patients Undergoing Chemotherapy and Radiation Therapy. Complement. Ther. Med. 21 (6), 712-723. doi:10.1016/ j.ctim.2013.08.018

Mendes, M. C. S., Paulino, D. S., Brambilla, S. R., Camargo, J. A., Persinoti, G. F., and Carvalheira, J. B. C. (2018). Microbiota Modification by Probiotic Supplementation Reduces Colitis Associated colon Cancer in Mice. World J. Gastroenterol. 24 (18), 1995-2008. doi:10.3748/wjg.v24.i18.1995

Meniailo, M. E., Malashchenko, V. V., Shmarov, V. A., Gazatova, N. D., Melashchenko, O. B., Goncharov, A. G., et al. (2018). Interleukin-8 Favors Pro-inflammatory Activity of Human Monocytes/macrophages. Int. Immunopharmacol 56, 217-221. doi:10.1016/j.intimp.2018.01.036

Mi, H., Dong, Y., Zhang, B., Wang, H., Peter, C. C. K., Gao, P., et al. (2017). Bifidobacterium Infantis Ameliorates Chemotherapy-Induced Intestinal Mucositis via Regulating T Cell Immunity in Colorectal Cancer Rats. Cell Physiol Biochem 42 (6), 2330-2341. doi:10.1159/000480005

Mirzaei, H., Khataminfar, S., Mohammadparast, S., Sales, S. S., Maftouh, M., Mohammadi, M., et al. (2016). Circulating microRNAs as Potential Diagnostic Biomarkers and Therapeutic Targets in Gastric Cancer: Current Status and
Future Perspectives. Curr. Med. Chem. 23 (36), 4135-4150. doi:10.2174/ 0929867323666160818093854

Mohania, D., Kansal, V. K., Kruzliak, P., and Kumari, A. (2014). Probiotic Dahi Containing Lactobacillus Acidophilus and Bifidobacterium Bifidum Modulates the Formation of Aberrant Crypt Foci, Mucin-Depleted Foci, and Cell Proliferation on 1,2-Dimethylhydrazine-Induced Colorectal Carcinogenesis in Wistar Rats. Rejuvenation Res. 17 (4), 325-333. doi:10.1089/rej.2013.1537

Mojibi, P., Tafvizi, F., and Bikhof Torbati, M. (2019). Cell-bound Exopolysaccharide Extract from Indigenous Probiotic Bacteria Induce Apoptosis in HT-29 Cell-Line. Iran J. Pathol. 14 (1), 41-51. doi:10.30699/ IJP.14.1.41

Mörkl, S., Lackner, S., Meinitzer, A., Mangge, H., Lehofer, M., Halwachs, B., et al. (2018). Gut Microbiota, Dietary Intakes and Intestinal Permeability Reflected by Serum Zonulin in Women. Eur. J. Nutr. 57 (8), 2985-2997. doi:10.1007/ s00394-018-1784-0

Moss, S. F. (2017). The Clinical Evidence Linking Helicobacter pylori to Gastric Cancer. Cell Mol Gastroenterol Hepatol 3 (2), 183-191. doi:10.1016/ j.jcmgh.2016.12.001

Mozaffari Namin, B., Daryani, N. E., Mirshafiey, A., Yazdi, M. K. S., and Dallal, M. M. S. (2015). Effect of Probiotics on the Expression of Barrett's Oesophagus Biomarkers. J. Med. Microbiol. 64 (4), 348-354. doi:10.1099/jmm.0.000039

Mushtaq, M., Gani, A., and Masoodi, F. A. (2019). Himalayan Cheese (Kalari/ Kradi) Fermented with Different Probiotic Strains: In Vitro Investigation of Nutraceutical Properties. LWT 104, 53-60. doi:10.1016/ j.lwt.2019.01.024

Nami, Y., Abdullah, N., Haghshenas, B., Radiah, D., Rosli, R., and Khosroushahi, A. Y. (2014). Assessment of Probiotic Potential and Anticancer Activity of Newly Isolated Vaginal Bacterium Lactobacillus Plantarum 5BL. Microbiol. Immunol. 58 (9), 492-502. doi:10.1111/1348-0421.12175

Nowell, P. C. (1976). The Clonal Evolution of Tumor Cell Populations. Science 194 (4260), 23-28. doi:10.1126/science.959840

Nozari, S., Faridvand, Y., Etesami, A., Ahmad Khan Beiki, M., Miresmaeili Mazrakhondi, S. A., and Abdolalizadeh, J. (2019). Potential Anticancer Effects of Cell wall Protein Fractions from Lactobacillus Paracasei on Human Intestinal Caco-2 Cell Line. Lett. Appl. Microbiol. 69 (3), 148-154. doi:10.1111/lam.13198

O’Mahony, L., Feeney, M., O’Halloran, S., Murphy, L., Kiely, B., Fitzgibbon, J., et al. (2001). Probiotic Impact on Microbial flora, Inflammation and Tumour Development in IL-10 Knockout Mice. Aliment. Pharmacol. Ther. 15 (8), 1219-1225. doi:10.1046/j.1365-2036.2001.01027.x

Oberreuther-Moschner, D. L., Jahreis, G., Rechkemmer, G., and Pool-Zobel, B. L. (2004). Dietary Intervention with the Probiotics Lactobacillus Acidophilus 145 and Bifidobacterium Longum 913 Modulates the Potential of Human Faecal Water to Induce Damage in HT29clone19A Cells. Br. J. Nutr. 91 (6), 925-932. doi:10.1079/BJN20041108

Ohara, T., and Suzutani, T. (2018). Intake of Bifidobacterium Longum and FructoOligosaccharides Prevents Colorectal Carcinogenesis. Euroasian J. Hepatogastroenterol 8 (1), 11-17. doi:10.5005/jp-journals-10018-1251

Ohigashi, S., Hoshino, Y., Ohde, S., and Onodera, H. (2011). Functional Outcome, Quality of Life, and Efficacy of Probiotics in Postoperative Patients with Colorectal Cancer. Surg. Today 41 (9), 1200-1206. doi:10.1007/s00595-0104450-6

Orlando, A., Linsalata, M., and Russo, F. (2016). Antiproliferative Effects on colon Adenocarcinoma Cells Induced by Co-administration of Vitamin $\mathrm{K} 1$ and Lactobacillus Rhamnosus GG. Int. J. Oncol. 48 (6), 2629-2638. doi:10.3892/ ijo. 2016.3463

Orlando, A., Messa, C., Linsalata, M., Cavallini, A., and Russo, F. (2009). Effects of Lactobacillus Rhamnosus GG on Proliferation and Polyamine Metabolism in HGC-27 Human Gastric and DLD-1 Colonic Cancer Cell Lines. Immunopharmacol Immunotoxicol 31 (1), 108-116. doi:10.1080/ 08923970802443631

Orlando, A., Refolo, M. G., Messa, C., Amati, L., Lavermicocca, P., Guerra, V., et al. (2012). Antiproliferative and Proapoptotic Effects of Viable or Heat-Killed Lactobacillus Paracasei IMPC2.1 and Lactobacillus Rhamnosus GG in HGC-27 Gastric and DLD-1 colon Cell Lines. Nutr. Cancer 64 (7), 1103-1111. doi:10.1080/01635581.2012.717676

Osterlund, P., Ruotsalainen, T., Korpela, R., Saxelin, M., Ollus, A., Valta, P., et al. (2007). Lactobacillus Supplementation for Diarrhoea Related to Chemotherapy 
of Colorectal Cancer: a Randomised Study. Br. J. Cancer 97 (8), 1028-1034. doi:10.1038/sj.bjc.6603990

Otte, J. M., Mahjurian-Namari, R., Brand, S., Werner, I., Schmidt, W. E., and Schmitz, F. (2008). Probiotics Regulate the Expression of COX-2 in Intestinal Epithelial Cells. Nutr. Cancer 61 (1), 103-113. doi:10.1080/01635580802372625

Paolillo, R., Romano Carratelli, C., Sorrentino, S., Mazzola, N., and Rizzo, A. (2009). Immunomodulatory Effects of Lactobacillus Plantarum on Human colon Cancer Cells. Int. Immunopharmacol 9 (11), 1265-1271. doi:10.1016/ j.intimp.2009.07.008

Pavón, M. A., Arroyo-Solera, I., Céspedes, M. V., Casanova, I., León, X., and Mangues, R. (2016). uPA/uPAR and SERPINE1 in Head and Neck Cancer: Role in Tumor Resistance, Metastasis, Prognosis and Therapy. Oncotarget 7 (35), 57351.

Ponder, B. A. (2001). Cancer Genetics. Nature 411 (6835), 336-341. doi:10.1038/ 35077207

Pourhanifeh, M. H., Vosough, M., Mahjoubin-Tehran, M., Hashemipour, M., Nejati, M., Abbasi-Kolli, M., et al. (2020). Autophagy-related microRNAs: Possible Regulatory Roles and Therapeutic Potential in and Gastrointestinal Cancers. Pharmacol. Res. 161, 105133. doi:10.1016/ j.phrs.2020.105133

Rasouli, B. S., Ghadimi-Darsajini, A., Nekouian, R., and Iragian, G. R. (2017). In Vitro activity of Probiotic Lactobacillus Reuteri against Gastric Cancer Progression by Downregulation of Urokinase Plasminogen Activator/ urokinase Plasminogen Activator Receptor Gene Expression. J. Cancer Res. Ther. 13 (2), 246-251. doi:10.4103/0973-1482.204897

Requena, T., Martínez-Cuesta, M. C., and Peláez, C. (2018). Diet and Microbiota Linked in Health and Disease. Food Funct. 9 (2), 688-704. doi:10.1039/ c7fo01820g

Rondanelli, M., Faliva, M. A., Perna, S., Giacosa, A., Peroni, G., and Castellazzi, A. M. (2017). Using Probiotics in Clinical Practice: Where Are We Now? A Review of Existing Meta-Analyses. Gut microbes 8 (6), 521-543. doi:10.1080/ 19490976.2017.1345414

Rubina, K. A., Sysoeva, V. Y., Zagorujko, E. I., Tsokolaeva, Z. I., Kurdina, M. I., Parfyonova, Y. V., et al. (2017). Increased Expression of uPA, uPAR, and PAI-1 in Psoriatic Skin and in Basal Cell Carcinomas. Arch. Dermatol. Res. 309 (6), 433-442. doi:10.1007/s00403-017-1738-z

Russo, F., Linsalata, M., and Orlando, A. (2014). Probiotics against Neoplastic Transformation of Gastric Mucosa: Effects on Cell Proliferation and Polyamine Metabolism. World J. Gastroenterol. 20 (37), 13258-13272. doi:10.3748/ wjg.v20.i37.13258

Russo, F., Orlando, A., Linsalata, M., Cavallini, A., and Messa, C. (2007). Effects of Lactobacillus Rhamnosus GG on the Cell Growth and Polyamine Metabolism in HGC-27 Human Gastric Cancer Cells. Nutr. Cancer 59 (1), 106-114. doi:10.1080/01635580701365084

Saber, A., Alipour, B., Faghfoori, Z., Mousavi Jam, A., and Yari Khosroushahi, A. (2017). Secretion Metabolites of Probiotic Yeast, Pichia Kudriavzevii AS-12, Induces Apoptosis Pathways in Human Colorectal Cancer Cell Lines. Nutr. Res. 41, 36-46. doi:10.1016/j.nutres.2017.04.001

Sadahiro, S., Suzuki, T., Tanaka, A., Okada, K., Kamata, H., Ozaki, T., et al. (2014). Comparison between Oral Antibiotics and Probiotics as Bowel Preparation for Elective colon Cancer Surgery to Prevent Infection: Prospective Randomized Trial. Surgery 155 (3), 493-503. doi:10.1016/j.surg.2013.06.002

Sadeghi-Aliabadi, H., Mohammadi, F., Fazeli, H., and Mirlohi, M. (2014). Effects of Lactobacillus Plantarum A7 with Probiotic Potential on colon Cancer and normal Cells Proliferation in Comparison with a Commercial Strain. Iran J. Basic Med. Sci. 17 (10), 815-819.

Said, H. M. (2012). Physiology of the Gastrointestinal Tract, Two Volume Set. Academic Press.

Sakatani, A., Fujiya, M., Ueno, N., Kashima, S., Sasajima, J., Moriichi, K., et al. (2016). Polyphosphate Derived from Lactobacillus Brevis Inhibits colon Cancer Progression through Induction of Cell Apoptosis. Anticancer Res. 36 (2), 591-598.

Sakatani, A., Fujiya, M., Ueno, N., Kashima, S., Sasajima, J., Moriichi, K., et al. (2016). Polyphosphate Derived from Lactobacillus Brevis Inhibits Colon Cancer Progression through Induction of Cell Apoptosis. Anticancer Res. 36 (2), 591-598.

Salas-Jara, M. J., Sanhueza, E. A., Retamal-Díaz, A., González, C., Urrutia, H., and García, A. (2016). Probiotic Lactobacillus Fermentum UCO-979C Biofilm
Formation on AGS and Caco-2 Cells and Helicobacter pylori Inhibition. Biofouling 32 (10), 1245-1257. doi:10.1080/08927014.2016.1249367

Sambrani, R., Abdolalizadeh, J., Kohan, L., and Jafari, B. (2019). Saccharomyces cerevisiae Inhibits Growth and Metastasis and Stimulates Apoptosis in HT-29 Colorectal Cancer Cell Line. Comp. Clin. Pathol. 28 (4), 985-995. doi:10.1007/ s00580-018-2855-6

Sánchez-Martínez, C., Lallena, M. J., Sanfeliciano, S. G., and de Dios, A. (2019). Cyclin Dependent Kinase (CDK) Inhibitors as Anticancer Drugs: Recent Advances (2015-2019). Bioorg. Med. Chem. Lett. 29 (20), 126637. doi:10.1016/j.bmcl.2019.126637

Sanders, M. E., Guarner, F., Guerrant, R., Holt, P. R., Quigley, E. M., Sartor, R. B., et al. (2013). An Update on the Use and Investigation of Probiotics in Health and Disease. Gut 62 (5), 787-796. doi:10.1136/gutjnl-2012-302504

Servin, A. L. (2004). Antagonistic Activities of Lactobacilli and Bifidobacteria against Microbial Pathogens. FEMS Microbiol. Rev. 28 (4), 405-440. doi:10.1016/j.femsre.2004.01.003

Shafabakhsh, R., Arianfar, F., Vosough, M., Mirzaei, H. R., Mahjoubin-Tehran, M., Khanbabaei, H., et al. (2021). Autophagy and Gastrointestinal Cancers: The behind the Scenes Role of Long Non-coding RNAs in Initiation, Progression, and Treatment Resistance. Cancer Gene Ther. 28 (12), 1229-1255.

Shaima'a Hamarsheh, R. Z. (2020). NLRP3 Inflammasome Activation in Cancer: a Double-Edged Sword. Front. Immunol. 11. doi:10.3389/fimmu.2020.01444

Sharaf, L. K., Sharma, M., Chandel, D., and Shukla, G. (2018). Prophylactic Intervention of Probiotics (L.Acidophilus, L.Rhamnosus GG) and Celecoxib Modulate Bax-Mediated Apoptosis in 1,2-Dimethylhydrazine-Induced Experimental colon Carcinogenesis. BMC Cancer 18 (1), 1111. doi:10.1186/ s12885-018-4999-9

Sharma, M., Chandel, D., and Shukla, G. (2019). Antigenotoxicity and Cytotoxic Potentials of Metabiotics Extracted from Isolated Probiotic, Lactobacillus Rhamnosus MD 14 on Caco-2 and HT-29 Human Colon Cancer Cells. Nutr. Cancer, 1-10. doi:10.1080/01635581.2019.1615514

Shiratsuchi, I., Akagi, Y., Kawahara, A., Kinugasa, T., Romeo, K., Yoshida, T., et al. (2011). Expression of IGF-1 and IGF-1R and Their Relation to Clinicopathological Factors in Colorectal Cancer. Anticancer Res. 31 (7), 2541-2545.

Shyu, P. T., Oyong, G. G., and Cabrera, E. C. (2014). Cytotoxicity of Probiotics from Philippine Commercial Dairy Products on Cancer Cells and the Effect on Expression of Cfos and Cjun Early Apoptotic-Promoting Genes and Interleukin-1 $\beta$ and Tumor Necrosis Factor- $\alpha$ Proinflammatory Cytokine Genes. Biomed. Res. Int. 2014, 491740. doi:10.1155/2014/491740

Singh, J., Rivenson, A., Tomita, M., Shimamura, S., Ishibashi, N., and Reddy, B. S. (1997). Bifidobacterium Longum, a Lactic Acid-Producing Intestinal Bacterium Inhibits colon Cancer and Modulates the Intermediate Biomarkers of colon Carcinogenesis. Carcinogenesis 18 (4), 833-841. doi:10.1093/carcin/18.4.833

Sivieri, K., Spinardi-Barbisan, A. L. T., Barbisan, L. F., Bedani, R., Pauly, N. D., Carlos, I. Z., et al. (2008). Probiotic Enterococcus Faecium CRL 183 Inhibit Chemically Induced colon Cancer in Male Wistar Rats. Eur. Food Res. Technol. 228 (2), 231-237. doi:10.1007/s00217-008-0927-6

Song, H., Wang, W., Shen, B., Jia, H., Hou, Z., Chen, P., et al. (2018). Pretreatment with Probiotic Bifico Ameliorates Colitis-Associated Cancer in Mice: Transcriptome and Gut flora Profiling. Cancer Sci. 109 (3), 666-677. doi:10.1111/cas.13497

Song, H., Zhou, L., Liu, D., Ge, L., and Li, Y. (2019). Probiotic Effect on Helicobacter pylori Attachment and Inhibition of Inflammation in Human Gastric Epithelial Cells. Exp. Ther. Med. 18 (3), 1551-1562. doi:10.3892/etm.2019.7742

Spechler, S. J. (2013). Barrett's Esophagus. Principles of Deglutition. Springer, 723-738. doi:10.1007/978-1-4614-3794-9_49

Sturgeon, C., and Fasano, A. (2016). Zonulin, a Regulator of Epithelial and Endothelial Barrier Functions, and its Involvement in Chronic Inflammatory Diseases. Tissue barriers 4 (4), e1251384. doi:10.1080/ 21688370.2016.1251384

Sun, X., and Kaufman, P. D. (2018). Ki-67: More Than a Proliferation Marker. Chromosoma 127 (2), 175-186. doi:10.1007/s00412-018-0659-8

Svensson, K. J., Welch, J. E., Kucharzewska, P., Bengtson, P., Bjurberg, M., Påhlman, S., et al. (2008). Hypoxia-mediated Induction of the Polyamine System Provides Opportunities for Tumor Growth Inhibition by Combined Targeting of Vascular Endothelial Growth Factor and Ornithine Decarboxylase. Cancer Res. 68 (22), 9291-9301. doi:10.1158/0008-5472.CAN-08-2340 
Tajadadi-Ebrahimi, M., Bahmani, F., Shakeri, H., Hadaegh, H., Hijijafari, M., Abedi, F., et al. (2014). Effects of Daily Consumption of Synbiotic Bread on Insulin Metabolism and Serum High-Sensitivity C-Reactive Protein Among Diabetic Patients: a Double-Blind, Randomized, Controlled Clinical Trial. Ann. Nutr. Metab. 65 (1), 34-41. doi:10.1159/000365153

Talero, E., Bolivar, S., Ávila-Román, J., Alcaide, A., Fiorucci, S., and Motilva, V. (2015). Inhibition of Chronic Ulcerative Colitis-Associated Adenocarcinoma Development in Mice by VSL\#3. Inflamm. Bowel Dis. 21 (5), 1027-1037. doi:10.1097/MIB.0000000000000346

Tamtaji, O. R., Heidari-Soureshjani, R., Mirhosseini, N., Kouchaki, E., Bahmani, F., Aghadavod, E., et al. (2019). Probiotic and Selenium Co-supplementation, and the Effects on Clinical, Metabolic and Genetic Status in Alzheimer's Disease: A Randomized, Double-Blind, Controlled Trial. Clin. Nutr. 38 (6), 2569-2575. doi:10.1016/j.clnu.2018.11.034

Tamtaji, O. R., Taghizadeh, M., Daneshvar Kakhaki, R., Kouchaki, E., Bahmani, F., Borzabadi, S., et al. (2019). Clinical and Metabolic Response to Probiotic Administration in People with Parkinson's Disease: A Randomized, DoubleBlind, Placebo-Controlled Trial. Clin. Nutr. 38 (3), 1031-1035. doi:10.1016/ j.clnu.2018.05.018

Tan, C. K., Said, S., Rajandram, R., Wang, Z., Roslani, A. C., and Chin, K. F. (2016). Pre-surgical Administration of Microbial Cell Preparation in Colorectal Cancer Patients: a Randomized Controlled Trial. World J. Surg. 40 (8), 1985-1992. doi:10.1007/s00268-016-3499-9

Tan, Q., Xu, H., Aguilar, Z. P., Peng, S., Dong, S., Wang, B., et al. (2013). Safety Assessment and Probiotic Evaluation of Enterococcus Faecium YF5 Isolated from Sourdough. J. Food Sci. 78 (4), M587-M593. doi:10.1111/1750-3841.12079

Taremi, M., Khoshbaten, M., Gachkar, L., EhsaniArdakani, M., and Zali, M. (2005). Hepatitis E Virus Infection in Hemodialysis Patients: a Seroepidemiological Survey in Iran. BMC Infect. Dis. 5 (1), 36. doi:10.1186/1471-2334-5-36

Teimoorian, F., Ranaei, M., Hajian Tilaki, K., Shokri Shirvani, J., and Vosough, Z. (2018). Association of Helicobacter pylori Infection with Colon Cancer and Adenomatous Polyps. Iran J. Pathol. 13 (3), 325-332.

Thirabunyanon, M., Boonprasom, P., and Niamsup, P. (2009). Probiotic Potential of Lactic Acid Bacteria Isolated from Fermented Dairy Milks on Antiproliferation of colon Cancer Cells. Biotechnol. Lett. 31 (4), 571-576. doi:10.1007/s10529-008-9902-3

Thirabunyanon, M., and Hongwittayakorn, P. (2013). Potential Probiotic Lactic Acid Bacteria of Human Origin Induce Antiproliferation of colon Cancer Cells via Synergic Actions in Adhesion to Cancer Cells and Short-Chain Fatty Acid Bioproduction. Appl. Biochem. Biotechnol. 169 (2), 511-525. doi:10.1007/ s12010-012-9995-y

Tiptiri-Kourpeti, A., Spyridopoulou, K., Santarmaki, V., Aindelis, G., Tompoulidou, E., Lamprianidou, E. E., et al. (2016). Lactobacillus Casei Exerts Anti-proliferative Effects Accompanied by Apoptotic Cell Death and Up-Regulation of TRAIL in colon Carcinoma Cells. PloS one 11 (2), e0147960. doi:10.1371/journal.pone.0147960

Tournier, C. (2013). The 2 Faces of JNK Signaling in Cancer. Genes \& cancer 4 (910), 397-400. doi:10.1177/1947601913486349

Urbanska, A. M., Bhathena, J., Martoni, C., and Prakash, S. (2009). Estimation of the Potential Antitumor Activity of Microencapsulated Lactobacillus Acidophilus Yogurt Formulation in the Attenuation of Tumorigenesis in $\mathrm{Apc}(\mathrm{Min} /+)$ Mice. Dig. Dis. Sci. 54 (2), 264-273. doi:10.1007/s10620-008-0363-2

Valadez-Bustos, N., Escamilla-Silva, E. M., García-Vázquez, F. J., Gallegos-Corona, M. A., Amaya-Llano, S. L., and Ramos-Gómez, M. (2019). Oral Administration of Microencapsulated B. Longum BAA-999 and Lycopene Modulates IGF-1/ IGF-1R/IGFBP3 Protein Expressions in a Colorectal Murine Model. Int. J. Mol. Sci. 20 (17), 4275. doi:10.3390/ijms20174275

Verma, A., and Shukla, G. (2013). Probiotics Lactobacillus Rhamnosus GG, Lactobacillus Acidophilus Suppresses DMH-Induced Procarcinogenic Fecal Enzymes and Preneoplastic Aberrant Crypt Foci in Early colon Carcinogenesis in Sprague Dawley Rats. Nutr. Cancer 65 (1), 84-91. doi:10.1080/01635581.2013.741746

Vigneri, P. G., Tirrò, E., Pennisi, M. S., Massimino, M., Stella, S., Romano, C., et al. (2015). The Insulin/IGF System in Colorectal Cancer Development and Resistance to Therapy. Front. Oncol. 5, 230. doi:10.3389/fonc.2015.00230

Vince, J. E., De Nardo, D., Gao, W., Vince, A. J., Hall, C., McArthur, K., et al. (2018). The Mitochondrial Apoptotic Effectors BAX/BAK Activate Caspase-3 and -7 to Trigger NLRP3 Inflammasome and Caspase-8 Driven IL-1 $\beta$ Activation. Cell Rep 25 (9), 2339-e4. e4. doi:10.1016/j.celrep.2018.10.103

Vogelstein, B., and Kinzler, K. W. (2004). Cancer Genes and the Pathways They Control. Nat. Med. 10 (8), 789-799. doi:10.1038/nm1087

Vogelstein, B., Papadopoulos, N., Velculescu, V. E., Zhou, S., Diaz, L. A., Jr., and Kinzler, K. W. (2013). Cancer Genome Landscapes. Science 339 (6127), 1546-1558. doi:10.1126/science.1235122

Walia, S., Kamal, R., Dhawan, D. K., and Kanwar, S. S. (2018). Chemoprevention by Probiotics during 1,2-Dimethylhydrazine-Induced Colon Carcinogenesis in Rats. Dig. Dis. Sci. 63 (4), 900-909. doi:10.1007/s10620-018-4949-Z

Walia, S., Kamal, R., Kanwar, S. S., and Dhawan, D. K. (2015). Cyclooxygenase as a Target in Chemoprevention by Probiotics during 1,2-dimethylhydrazine Induced colon Carcinogenesis in Rats. Nutr. Cancer 67 (4), 603-611. doi:10.1080/01635581.2015.1011788

Wang, C. S., Li, W. B., Wang, H. Y., Ma, Y. M., Zhao, X. H., Yang, H., et al. (2018). VSL\#3 Can Prevent Ulcerative Colitis-Associated Carcinogenesis in Mice. World J. Gastroenterol. 24 (37), 4254-4262. doi:10.3748/wjg.v24.i37.4254

Wang, C. S., Li, W. B., Wang, H. Y., Ma, Y. M., Zhao, X. H., Yang, H., et al. (2018). VSL\#3 Can Prevent Ulcerative Colitis-Associated Carcinogenesis in Mice. World J. Gastroenterol. 24 (37), 4254-4262. doi:10.3748/wjg.v24.i37.4254

Wang, F., Song, M., Lu, X., Zhu, X., and Deng, J. (2021). Gut Microbes in Gastrointestinal Cancers. Seminars in Cancer Biology.

Wang, H., Bastian, S. E., Lawrence, A., and Howarth, G. S. (2015). Factors Derived from Escherichia coli Nissle 1917, Grown in Different Growth media, Enhance Cell Death in a Model of 5-Fluorouracil-Induced Caco-2 Intestinal Epithelial Cell Damage. Nutr. Cancer 67 (2), 316-326. doi:10.1080/01635581.2015.990570

Welte, Y., Adjaye, J., Lehrach, H. R., and Regenbrecht, C. R. (2010). Cancer Stem Cells in Solid Tumors: Elusive or Illusive? Cel Commun Signal 8 (1), 6-10. doi:10.1186/1478-811X-8-6

Wood, D. J., and Endicott, J. A. (2018). Structural Insights into the Functional Diversity of the CDK-Cyclin Family. Open Biol. 8 (9), 180112. doi:10.1098/ rsob. 180112

Worthley, D. L., Le Leu, R. K., Whitehall, V. L., Conlon, M., Christophersen, C., Belobrajdic, D., et al. (2009). A Human, Double-Blind, Placebo-Controlled, Crossover Trial of Prebiotic, Probiotic, and Synbiotic Supplementation: Effects on Luminal, Inflammatory, Epigenetic, and Epithelial Biomarkers of Colorectal Cancer. Am. J. Clin. Nutr. 90 (3), 578-586. doi:10.3945/ajcn.2009.28106

Wu, Q., Wu, W., Fu, B., Shi, L., Wang, X., and Kuca, K. (2019). JNK Signaling in Cancer Cell Survival. Med. Res. Rev. 39 (6), 2082-2104. doi:10.1002/med.21574

Xie, H., Lu, Q., Wang, H., Zhu, X., and Guan, Z. (2018). Effects of Probiotics Combined with Enteral Nutrition on Im-Mune Function and Inflammatory Response in Postoperative Patients with Gastric Cancer.

Yamazaki, K., Tsunoda, A., Sibusawa, M., Tsunoda, Y., Kusano, M., Fukuchi, K., et al. (2000). The Effect of an Oral Administration of Lactobacillus Casei Strain Shirota on Azoxymethane-Induced Colonic Aberrant Crypt Foci and colon Cancer in the Rat. Oncol. Rep. 7 (5), 977-982. doi:10.3892/or.7.5.977

Yang, Y., Xia, Y., Chen, H., Hong, L., Feng, J., Yang, J., et al. (2016). The Effect of Perioperative Probiotics Treatment for Colorectal Cancer: Short-Term Outcomes of a Randomized Controlled Trial. Oncotarget 7 (7), 8432-8440. doi:10.18632/oncotarget.7045

You, H. J., Oh, D. K., and Ji, G. E. (2004). Anticancerogenic Effect of a Novel Chiroinositol-Containing Polysaccharide from Bifidobacterium Bifidum BGN4. FEMS Microbiol. Lett. 240 (2), 131-136. doi:10.1016/ j.femsle.2004.09.020

Yuasa, Y. (2003). Control of Gut Differentiation and Intestinal-type Gastric Carcinogenesis. Nat. Rev. Cancer 3 (8), 592-600. doi:10.1038/nrc1141

Zhang, J. W., Du, P., Gao, J., Yang, B. R., Fang, W. J., and Ying, C. M. (2012). Preoperative Probiotics Decrease Postoperative Infectious Complications of Colorectal Cancer. Am. J. Med. Sci. 343 (3), 199-205. doi:10.1097/ MAJ.0b013e31823aace6

Zhang, M., Wang, F., Jiang, L., Liu, R., Zhang, L., Lei, X., et al. (2013). Lactobacillus Salivarius REN Inhibits Rat Oral Cancer Induced by 4-nitroquioline 1-oxide. Cancer Prev. Res. (Phila) 6 (7), 686-694. doi:10.1158/1940-6207.CAPR-12-0427

Zhang, M. M., Cheng, J. Q., Xia, L., Lu, Y. R., and Wu, X. T. (2011). Monitoring Intestinal Microbiota Profile: a Promising Method for the Ultraearly Detection of Colorectal Cancer. Med. Hypotheses 76 (5), 670-672. doi:10.1016/ j.mehy.2011.01.028 
Zhang, Y., Ma, C., Zhao, J., Xu, H., Hou, Q., and Zhang, H. (2017). Lactobacillus Casei Zhang and Vitamin K2 Prevent Intestinal Tumorigenesis in Mice via Adiponectin-Elevated Different Signaling Pathways. Oncotarget 8 (15), 24719-24727. doi:10.18632/oncotarget.15791

Zhou, D. Y., Ding, N., Du, Z. Y., Cui, X. X., Wang, H., Wei, X. C., et al. (2014). Curcumin Analogues with High Activity for Inhibiting Human Prostate Cancer Cell Growth and Androgen Receptor Activation. Mol. Med. Rep. 10 (3), 1315-1322. doi:10.3892/mmr.2014.2380

Zhou, Z., Chen, J., Yao, H., and Hu, H. (2018). Fusobacterium and Colorectal Cancer. Front. Oncol. 8, 371. doi:10.3389/fonc.2018.00371

Zhu, J., Zhu, C., Ge, S., Zhang, M., Jiang, L., Cui, J., et al. (2014). Lactobacillus Salivarius Ren Prevent the Early Colorectal Carcinogenesis in 1, 2Dimethylhydrazine-Induced Rat Model. J. Appl. Microbiol. 117 (1), 208-216. doi:10.1111/jam.12499

Zinatizadeh, N., Khalili, F., Fallah, P., Farid, M., Geravand, M., and Yaslianifard, S. (2018). Potential Preventive Effect of Lactobacillus Acidophilus and Lactobacillus Plantarum in Patients with Polyps or Colorectal Câncer. Arq Gastroenterol. 55 (4), 407-411. doi:10.1590/S0004-2803.201800000-87

Zitvogel, L., Ma, Y., Raoult, D., Kroemer, G., and Gajewski, T. F. (2018). The Microbiome in Cancer Immunotherapy: Diagnostic Tools and Therapeutic Strategies. Science 359 (6382), 1366-1370. doi:10.1126/science.aar6918

Zuccotti, G. V., Meneghin, F., Raimondi, C., Dilillo, D., Agostoni, C., Riva, E., et al. (2008). Probiotics in Clinical Practice: an Overview. J. Int. Med. Res. 36 (1_Suppl. 1), 1A-53A. doi:10.1177/14732300080360S101
Zununi Vahed, S., Barzegari, A., Rahbar Saadat, Y., Goreyshi, A., and Omidi, Y. (2017). Leuconostoc Mesenteroides-Derived Anticancer Pharmaceuticals Hinder Inflammation and Cell Survival in colon Cancer Cells by Modulating NF- $\mathrm{B} / \mathrm{AKT} / \mathrm{PTEN} / \mathrm{MAPK}$ Pathways. Biomed. Pharmacother. 94, 1094-1100. doi:10.1016/j.biopha.2017.08.033

Conflict of Interest: The authors declare that the research was conducted in the absence of any commercial or financial relationships that could be construed as a potential conflict of interest.

Publisher's Note: All claims expressed in this article are solely those of the authors and do not necessarily represent those of their affiliated organizations, or those of the publisher, the editors, and the reviewers. Any product that may be evaluated in this article, or claim that may be made by its manufacturer, is not guaranteed or endorsed by the publisher.

Copyright (c) 2021 Davoodvandi, Fallahi, Tamtaji, Tajiknia, Banikazemi, Fathizadeh, Abbasi-Kolli, Aschner, Ghandali, Sahebkar, Taghizadeh and Mirzaei. This is an open-access article distributed under the terms of the Creative Commons Attribution License (CC BY). The use, distribution or reproduction in other forums is permitted, provided the original author(s) and the copyright owner(s) are credited and that the original publication in this journal is cited, in accordance with accepted academic practice. No use, distribution or reproduction is permitted which does not comply with these terms. 